\title{
LOS DIARIOS DEL EXILIO DE LOS JESUITAS DE LA PROVINCIA DE ANDALUCIA (1767)
}

\author{
Enrique GIMÉNEZ LÓPEZ \\ Mario MARTÍNEZ GOMIS \\ Universidad de Alicante
}

\section{Diarios y diaristas}

El objeto del presente artículo es ofrecer la edición de cuatro pequeños diarios manuscritos relativos a las incidencias del viaje realizado por los jesuitas de la Provincia de Andalucía desde España hasta la isla de Córcega, a raiz del decreto de expulsión de la Compañía en abril de 1767. Se trata de cuatro documentos inéditos, aunque conocidos por algunos historiadores ${ }^{1}$, que ofrecen al lector, con la inmediatez y urgencia propia de una redacción condicionada por los acontecimientos, la dimensión dramática de un éxodo que, a diferencia de otros sucesos similares - el extrañamiento de los judíos o el de la población morisca - cuenta con el testimonio directo de algunos de sus protagonistas. Nos referimos al Diario breve de la navegación a Italia, de autor anónimo, al Diario de la navegación de los Jesuitas de la Provincia de Andalucía desde el Puerto de Santa María y Málaga a Civitavecchia, original del padre Diego de Tienda, la Continuación del diario del viaje de los jesuitas de Andalucía desde Civitavecchia a 31 de mayo de 1767 , debido a la pluma del P. Alonso Pérez y, por último, al Viaje de los áltimos jesuitas andaluces y descripción de Ajaccio, que redactó el P. Marcos Cano².

Son diversos los "diarios", "memoriales" y "relaciones" escritos por jesuitas que se ocupan de narrar los pormenores y sucesos más relevantes de la expulsión de la Compañía de los dominios del rey de España y de las peripecias que hubieron de sufrir sus micmbros desde el momento de su confinamiento en sus casas y colegios de la Península, durante los días 1 y 2 de abril de 1767, hasta la arribada definitiva a los Estados Pontificios. No faltando, tampoco, los referentes a los jesuitas americanos llegados a Italia en otoño de 1768 y otros relativos a los jesuitas procedentes de Filipinas dos años más tarde, en octubre de 1770. 
Entre esos escritos es sobradamente conocido - aunque no tan consultado el firmado por el P. Manuel Luengo ${ }^{3}$, que consta de 63 volúmenes manuscritos y que abarca un período de 49 años desde el 2 de abril de 1767 hasta el 30 de septiembre de 1815 , obra que permanece inédita aunque alguna de sus páginas hayan sido objeto de estudio, c incluso transcritas, por el también jesuita P. Constancio Eguía Ruiz 4 . Otra importante crónica de los primeros momentos del exilio se debe al famoso literato P. Francisco de Isla ${ }^{5}$, concluida en Calvi (Córcega) en febrero de 1768 y publicada en Madrid en 1882. Ambos, en principio, se ocuparon de narrar las desventuras de los jesuitas instalados en España, mientras que otras dos obras, la del P. José Manuel Peramás 6 narrando la historia del exilio de los jesuitas de la Provincia de Paraguay, y la del P. Francisco Javier Puig7 haciendo lo propio con la de los jesuitas de Filipinas, se convierten en paradigmas de diversos relatos conocidos que se ocupan del larguísimo peregrinaje de los hijos de San Ignacio desde las Provincias de ultramar hasta su destino final en la Península italiana ${ }^{8}$.

Si descartamos estas últimas obras, inéditas en su mayor parte, y nos ceñimos, a las cuatro citadas con anterioridad, podremos observar una serie de cuestiones que nos sirven para destacar la originalidad o, si se prefiere, los particularismos de los tex los de los jesuitas andaluces que pretendemos presentar. En primer lugar, el Diario del P. Lucngo, como puso de relieve Constancio Eguía, comenzó a escribirse pocos días después del 2 de abril de 1767 como una especie de entretenimiento, para ir cobrando mayor envergadura conforme su autor tomaba conciencia de su trascendencia histórica y acabar convirtiéndose, de un diario relativo a los sucesos acontecidos a los miembros de la provincia de Castilla, en una auténtica historia de la Compañía, sobre todo a partir de la llegada de los jesuitas a Córcega e Italia. La premeditación, $\mathrm{c}$ incluso, la intencionalidad de la obra, documentada con gran cantidad de testimonios y vivencias de sus correligionarios, la firme voluntad de su autor de continuarla, incluso después de la extinción de la Orden en 1773 para que "sirva escribía - de aquí a un siglo, o medio, por lo menos, para formar una historia sincera de la presente persecución de la Compañía", habla muy a las claras de su envergadura, al igual que el hecho de prolongarla hasta 1814, año del restablecimiento de la Orden, o del cuidado que tuvo de realizar copias de seguridad de la misma.

De igual manera el Memorial del P. Isla, como su propio título hace suponer, es una obra de carácter reivindicativo y por supuesto apologética -como la de Luengo, en cierta medida- destinada a presentar a Carlos III "la verdad más pura, y más desnuda de toda ponderación y artificio" 10 sobre los excesos, irregularidades y violencias que se cometieron sobre los expulsos desde el instante de su confinamiento hasta algunos meses después de su estancia en Córcega. Sc trata, también, de un trabajo cuidadosamente escrito, con elementos dramáticos muy bien dosificados, y en el que Isla se convierte en el protavoz de un colectivo que, aunque dispuesto a acatar las órdenes del Rey, exige un trato más humano y benévolo tal y como cl monarca había dispuesto en su decreto de expulsión, denunciando determinados abusos de los agentes y comisarios encargados de cumplir la normativa del extrañamiento. Como en cl caso de Luengo, el Memorial de Isla, aunque no ceñido al minu- 
cioso discurrir cronológico de un diario, sólo pudo elaborarse recogiendo informaciones puntualísimas de lo sucedido en todos y cada uno de los colegios y casas de la Provincia de Castilla, así como en los trayectos que habían de conducirles a los puertos de cmbarque. La prolijidad de detalles es asombrosa y como fuente histórica - para leer con cierta cautela- no tiene desperdicio, encontrándose a la misma altura que la del P. Luengo al convertirse, una vez en Córcega, en relato concerniente a toda la Compañía y si exceptuamos el menor espacio temporal analizado por el autor del Fray Gerundio.

Prueba de que el Memorial -y quizá algunas informaciones de Luengo-se fundaron en un previo trabajo de recopilación e información colectiva, son las palabras de Luis Gnecco, uno de los comisarios genoveses al servicio del gobierno de Madrid, encargado de controlar a los jesuitas en Córcega, de asegurarles el pago de la pensión, el suministro de víveres, los alojamientos, etc., pero también con la misión de vigilar todos sus movimientos. Este personaje escribía a Grimaldi el 20 de diciembre de 1767 desde Córcega: “...en lo relatibo a la conducta de los extrañados no hai por aora otra particularidad que la de estar secretamente algunos componiendo una relación de lo passado en su expulsión de España y destino de Córcega" "l.

El relato del P. José Manuel Peramás acerca de las vicisitudes de los jesuitas del Paraguay, o el del P. Puig sobre los filipinos, para abreviar, presentan unos rasgos diferenciales, ceñidos, sin duda, al propio devenir de los acontecimientos y, como no, a la propia personalidad de sus autores. En cuanto a los distintos sucesos vividos en relación con los jesuitas de la Península, es necesario señalar que miemtras el traslado de estos últimos hasta Córcega duró entre uno y tres meses, el de los paraguayos se prolongó poco más de un año (entre el 11 de julio de 1767 y 4 de agosto de 1768) ${ }^{12}$, y el de los filipinos entre el 18 de mayo de 1768 , en que fueron apresados, y el 29 de octubre de 1770 en que llegaron a Italia ${ }^{13}$, circunstancias que en ambos casos mediatizaron sus respectivos relatos. Peramás, por cjemplo, pudo abordar en sus páginas una breve historia de su provincia y describió la vida y costumbres de los indigenas de sus territorios. De igual modo el registro cotidiano de los sucesos, tal vez por la monotonía de muchas jornadas, o por la mayor serenidad a la hora de juzgar su situación y la de sus compañeros, se vió en ocasiones sustituido por un breve resumen de lo sucedido a lo largo de un mes o espacios más largos. Introdujo curiosas digresiones acerca de cuanto veía novedoso, y sólo recobró el pulso de los acontecimientos diarios, con muy breves y urgentes pinceladas, al final de su obra, a la hora de llegar a Italia. Lo mismo ocurre con el manuscrito del P. Puig, hombre igualmente dotado de un vivo estilo descriplivo y que hizo el viaje por el Pacífico teniendo que cruzar territorio mejicano para enlazar con el Atlántico. Cushner, que estudió su obra, posee sus lógicas sospechas acerca de la elaboración del diario presuponiendo, quizá, un borrador anterior ${ }^{14}$.

¿En qué radica, por lo tanto, la originalidad de los diarios de los Padres andaluccs?. En primer lugar señalemos que, en realidad, se trata de cuatro opúsculos. El primero de cllos, el Diario breve de la navegación a ltalia, de autor anónimo, cons- 
ta tan sólo de 13 páginas manuscritas en las que se condensa, a modo de escueta agenda, la fecha de navegación y algún párrafo determinante de la singladura, ganando mínimamente en elocuencia y extensión sólo en contadas ocasiones, cuando algún hecho parecía relevante a los ojos de su autor. Los dos diarios siguientes, el del P. Diego de Tienda, y el del P. Alonso Pérez, constituyen tal y como puede advertirse a través de los títulos expuestos al inicio de este trabajo, una misma obrita en dos partes: la de Tienda que narra los sucesos acaecidos desde la salida del Puerto de Santa María el 2 de mayo de 1767, hasta la llegada a Civitavecchia el 31 de mayo del mismo año, y la del P. Alonso Pérez que no es sino la continuación del mismo viaje retomando la acción en la última de las fechas citadas y concluyendo su narración el 14 de julio de 1767 tras el desembarco en Algayola. Ambos escritos hacen referencia al mismo espacio cronológico que el diario anónimo. El cuarto relato, el del P. Alonso Cano, no es en realidad un diario sino unos apuntes tan sólo de otro viaje distinto que tuvo lugar unos meses más tarde al citado con anterioridad: el de los Padres Procuradores que habían quedado en sus Colegios y establecimientos de la Península para proceder junto a los agentes reales, al inventariado de los bienes de la Compañía. Viaje realizado entre el 6 de octubre y el 5 de noviembre de 1767. Consta de 11 páginas manuscritas $\mathrm{y}$, tras describir en las tres primeras el trayecto entre Cartagena y Ajaccio, dedica el resto a exponer un curioso retrato literario de esta ciudad y sus gentes.

Es ahora cuando, en realidad, podemos contestar a nuestra pregunta anterior acerca de las peculiaridades de estos diarios. En concreto sobre los de Diego Tienda y Alonso Pérez y acerca de algunos aspectos comunes que presenta el de autor anónimo. La originalidad de los mismos radica, fundamentalmente, y en correspondencia con su brevedad, y con el ritmo más acelerado e imprevisto de los acontecimientos que se narran, en su espontaneidad e inmediatez. Características a las que se añade la ausencia de otra pretensión que no sea la de captar lo más relevante del momento vivido, estableciendo así un punto de apoyo cronológico para un recreo posterior de la memoria. En otras palabras: todo parece indicar que nos encontramos ante una sucesión de urgentes anotaciones cotidianas que bien pudieran constituir cl borrador de una serie de proyectos de "diarios" más elaborados ${ }^{15}$ y es precisamente, en esa falta de pretensión literaria, en esa sóla intención de registrar lo más sobresaliente, sin otro tipo de artificio, donde radica a nuestro juicio, el valor testimonial de estos documentos que se ven así despojados de los tintes apologéticos que en otros casos pudieran empañar la realidad de los hechos.

La precisión con que se anotan las horas en las páginas del diario del P. Tienda, por ejemplo, y que no pudieron incluirse con mucha posterioridad a los sucesos, a no ser que poseyese una memoria prodigiosa o excepcional, confirma su auténtico carácter de apuntes diarios y elude toda sospecha de relato pausado y reflexivo. EI mismo laconismo que preside los resúmenes de los días iniciales del viaje, cuando la resignación parecía ser la tónica de un destierro que comenzaba a asumirse, y la mayor locuacidad, teñida de incertidumbre y conatos de desesperación, que se advierte en los días que siguieron a la negativa del Papa Clemente XIII a recibirlos 
en los Estados Pontificios, cuando el P. Alonso Pérez tomó el relevo del P. Tienda como diarista, son también elocuentes acerca del proceso diario de redacción en íntima conexión con el dramatismo de las situaciones vividas.

Las dos partes de este diario se encuentran, por lo tanto, claramente dilerenciadas, más a causa de la índole de los acontecimientos, que como consecuencia de su distinta autoría. Los hechos de las primeras jornadas relativas al embarque y travesía hasta Civitavecchia, constituyen un ejercicio sereno en el que se recogen Jos detalles típicos de un viaje por mar no excesivamente accidentado: los vientos al cruzar el estrecho de Gibraltar, la calma chicha frente a las costas de Málaga, el racionamiento de víveres de calidad a pesar de las previsiones (el pan, por ejemplo), la inquietud ante el avistamiento lejano de fustas argelinas, las terribles e inesperadas tormentas que desarbolan los barcos, los separan y extravían, etc. Acontecimientos no tan extraordinarios y que se asemejan bastante a otros viajes por el Mediterráneo durante la misma cstación y a lo largo de la misma centuria. ${ }^{16}$ Ciertas reflexiones personales, anotaciones acerca de algunos pormenores sobre el discurrir de la vida cotidiana en los navíos y el estado de ánimo de los viajeros, colorean cstas páginas cuyo interés reside en el esfuerzo de los jesuitas por mantener la cohesión de los distintos colegios, reanudar las actividades intelectuales y escolares, y no dejarse vencer por la adversidad aceptando los designios de la Providencia como una suerte de prueba especial.

A partir del 31 de mayo el texto, coincidiendo con el relevo de pluma, cambiará de tono. El P. Alonso Pérez estrenó sus páginas de este modo: "Día 31 de Mayo. Este día por la mañana a las ocho, cuando creíamos estar de fïme ya en el Estado eclesiástico, y hechos los líos de ropa para desembarcar tuvimos de repente la noticia de que teníamos que volvernos por haber orden de Su Santidad de que no saltássemos a tierra ningún jesuita (...). Díjose que Su Santidad no nos admitía por la careslía y falta de víveres de sus Estados, y que ésta era la respuesta que había dado al Rey de España, excusándose de ello, conque nos hallamos en el desconsuelo que se puede inferir de vernos sin hallar un palmo de tierra en que fijar pie, volviendo a tener que hacer nuevo sacrificio a Dios de nosotros en este total desamparo y abandono de las criaturas que nos dejaban a sóla la Providencia de Dios por estos mares, sin saber cual había de ser nuestro paradero..."l7.

Era el preludio de un mes terrible, no sólo por las indecisiones que se filltraban acerca del parecer de los comandantes de los convoyes, sino por la certeza, al fin, de saber su último destino: Córcega. La amargura, los tintes sombrios con que se describía esta isla, resumen el estado de ánimo de los jesuitas: "una tierra a quien los mapas y geografos hacen de aire grueso y poco sano, inculta, y sin aquellas providencias necesarias para la subsistencia aún en lo más preciso (...), iremos a unos lugarcillos provistos de casas de paja (...), fronteros a las ticras de los rebeldes de Córcega que están en guerra con la República de Génova y que a pic llano podrán entrar cuando quieran en nuestras casas o casillas, y entrar a saco cuánto lengamos"18. La sensación total de abandono aparece también por primera vez en el diario: "tendremos que levantar los ojos al cielo, de donde únicamente podremos reci- 
bir alivio, que no podrán darnos nuestros padres y amigos por no poder enviarlo, ni tener por donde, o por no saber de nosotros, ni de nuestro paradero en esta tierra tan apartada de todo comercio y puesta en medio de estos mares"19.

Sin llegar a la desesperación se advierten esos síntomas de temor que parecen resquebrajar ya muchas voluntades que habían superado la adversidad durante dos meses y pico de confinamiento y traslado. Del mismo modo, y conforme enrarezcan los víveres, las noticias acerca de las secularizaciones, de los proyectos de huida, harán su aparición. Esto ocurrirá especialmente durante los días en que los distintos comvoyes de jesuitas coincidan frente a las costas de Córcega aguardando el definitivo desembarco, cuando los padres de unas y otras provincias vuelvan a comunicarse y a contrastar sus experiencias, cuando se filtren las noticias de las desventuras propias y ajenas. Del mismo modo, en estas páginas finales del diario, aparecen otros rasgos que definen el momento: tras la resignación, tras el obligado silencio, los jesuitas parecen afilar las armas de la resistencia, o mejor de su autodefensa, al tiempo que una serie de rumores hablan de solidaridades ocultas en España o de la posibilidad de un regreso tras el que parece brillar un rayo de esperanza. Así, el 26 de julio escribía el P. Alonso: "tuvimos noticia de cómo un religioso franciscano supo el Decreto de nuestro extrañamiento $\mathrm{cl}$ jucbes de la semana antes de que se ejecutase y las diligencias que hizo con esta noticia el P. Eustaquio de Medina"20. Y el 2 de julio: "supimos que por el P. Barona (confesor de la Reyna Doña María Bárbara que también viene aquí con el comboy de Toledo) habían sabido los Padres de Madrid algunos días antes el Decreto de nuestra expulsión"21.

Las sucintas anotaciones del Diario anónimo corroboran los hitos más destacados de los diarios que acabamos de describir, sin añadir nada novedoso. Cosa bien distinta ocurre en el caso del Viaje del P. Marcos Cano, ya en otro momento histórico, es decir, realizado cuando sus hermanos de religión habían vivido el cúmulo de incertidumbres descritas y se hallaban aposentados en Córcega. Su relato es de corte impresionista y se limita a narrar una tormenta en alta mar y a describirnos Ajaccio. Como otros jesuitas que conocían a ciencia cierta su destino -los americanos, por ejemplo- Marcos Cano no pudo eludir la cita obligada al destierro de Séneca en la isla. El paraguayo P. Peramás hizo lo propio al avistarla y, tal vez más acostumbrado a una ruda existencia en las misiones, no vió Córcega con tintes tan oscuros como sus compañeros, es más, atribuyó a unos dísticos de Pedro Bercio inspirados en los comentarios de Séneca, la mala imagen que se tenía de la isla ${ }^{22}$. Pero no es esto lo que importa del breve viaje del P. Marcos Cano. Su interés histórico o humano es más bien escaso. Importa, en cambio, su predisposición a la escritura, su talante a la hora de registrar la curiosa visión de Ajaccio que conecta con alguno de los pasajes que hemos tomado como punto de referencia al principio de este trabajo: el del P. Peramás y $\mathrm{cl}$ del P. Puig. El P. Marcos Cano se detuvo en detalles descriptivos de tipo costumbrista o ctnológico, unas pinceladas tan sólo, pero las suficientes para poner de manifiesto ese rasgo tan peculiar en muchos miembros de la Compañía tendente a adentrarse en 
el conocimiento de sus lugares de destino para hacer más eficaz su labor dejando informaciones precisas a sus sucesores ${ }^{23}$. El P. Marcos Cano, en un alarde de síntesis, describió lo más sobresaliente de la ciudad, sus actividades económicas, sus recursos, cómo eran y cómo vestían sus gentes, e incluso, valorando los ingresos de los canónigos isleños, estableció una curiosa conclusión acerca del tipo de vida que podrían llevar allí los jesuitas en razón de su pensión anual. Los paralelismos con los diarios del P. Peramás y del P. Puig son evidentes cuando éstos trazan, con mayor detalle y abundamiento, la vida de los indios o de los fillipinos. Pero son mayores aún las semejanzas con la prosa urgente del P. Peramás al cruzar Italia hacia los Estados Pontificios: anotaba, como el P. Marcos Cano, reseñas acerca de la vestimenta de los italianos, de sus medios de transporte, del estado de sus campos de labor, etc. Una hábito que contenía el fructífero germen de la tarea cultural que los jesuitas iban a desarrollar en tierras italianas, tal y como estudió el P. Miguel Batllori24.

Esta última observación nos obliga a trazar un brevísimo bosquejo acerea de los autores de los diarios citados. La información la debemos al P. Francisco Borja Medina en su estudio sobre la Provincia jesuítica de Andalucía ${ }^{25}$. No nos encontramos ante escritores de primera fila, sino más bien ante un pequeño grupo de religiosos que, dedicados a actividades intelectuales dentro de su orden, se encontraban en disposición de llevar a cabo un ejercicio literario impulsado por la trascendencia de los acontecimicntos que les tocó vivir. Esta razón, unida a la necesidad de ocupar el tiempo en las embarcaciones, o probablemente un mandato de sus superiores, dió alas a sus plumas. Sobre este último aspecto conviene señalar las palabras que cierran el Viaje del P. Marcos Cano, un concluyente "hasta aquí es lo que puedo informar" 26 , frase que otorga un indudable aire de misiva a su escrito de no tratarse, como pudiera ocurrir, de un recurso retórico. El P. Tienda, por su parte, a la hora de ceder la continuación de su diario al $\mathbf{P}$. Alonso Pérez, tras apuntar los últimos sucesos del día 31 de mayo, rompió voluntariamente la narración cronológica para ofrecer, bajo el epígrafe de "notas", una especie de recapitulación en la que la nómina de los jesuitas que quedaron en España a causa de la edad o cnfermedades es sin duda lo más sobresaliente de cara a mostrar a mostrar una cierta responsabilidad informativa.

Los rasgos comunes de los PP. Tienda, Alonso Pérez y Marcos Cano fueron, además de su origen andaluz, su dedicación dentro de la orden a las actividades docentes. El P. Diego de Tienda había nacido el 13 de junio de 1726 en Bacna (Córdoba), siendo recibido en la Compañía el 26 de agosto de 1740, y llevado a cabo su noviciado en San Luis de Sevilla. Ordenado sacerdote en Guadix el 17 de septiembre de 1750, hizo la tercera probación en Baeza y pasó a dedicarse a la cnseñanza: primero a la Gramática y Retórica en Granada y en Carmona y, desde 1765 hasta el momento de la expulsión, como profesor de Metafísica en el colcgio de San Hermenegildo de Sevilla. Murió en el destierro en paradero desconocido y, que sepamos, no dejó otra obra escrita ${ }^{27}$.

El P. Alonso Pérez era natural de Córdoba, nacido el 24 de septiembre de 1723 
y es el único de los tres diaristas que presenta un curriculum de actividades literarias de cierta solidez. Fue admitido en la Compañía en el colegio de San Hermenegildo de Sevilla, y su periplo formativo lo realizó cursando Humanidades (Carmona), Filosofía (Granada) y Teología (San Hermenegildo). Tras su ordenación sacerdotal en Sevilla en 1748, y cumplida su tercera probación en Santiago de Baeza, se dedicó a la enseñanza dentro de la orden impartiendo Gramática en los colegios de Arcos, Morón de la Frontera y Andújar, Teologia en Málaga, y Filosofía en Sevilla, sorprendiéndole la expulsión enseñando Teología en Jaen. Para esta fecha ya había dado a la imprenta, aunque de manera anónima, una Relación sumaria de las escuelas de leer y escribir de Sevilla (1765). Debido a su experiencia en tal materia, una vez suprimida la Compañía, el Senado de Pessaro le encargó la reforma de sus escuelas públicas. De igual modo, y bajo la protección del obispo de Gubbio y Trani, ejerció como teólogo en la diócesis y fue rector de su Seminario. En 1797 regresó a España muriendo dos años después a consecuencia de la epidemia de peste que padeció Sevilla. Escribió, además de otros manuscritos sobre el destierro, obras de carácter histórico, canónico, teológico, litúrgico y poesías latinas que también quedaron inéditas ${ }^{28}$.

El P. Marcos Cano había nacido en Begíjar (Jaen) el 9 de febrero de 1730 y tras ingresar en el colegio de la Compañía de Ubeda, en 1750, hizo su noviciado en San Luis de Sevilla, cursando más tarde Filosofía y Teología en el colegio de San Hermenegildo de la misma ciudad. Fue preceptor de Gramática en Fregenal, pasando de nuevo a San Hermenegildo en calidad de procurador de la institución, oficio que ostentaba en el momento de la expulsión. A diferencia de sus compañeros partió al destierro meses más tarde, el 9 de octubre de 176729 , junto a otros procuradores que habían quedado en sus casas e institutos para dar cuenta de los bicnes a la Real Hacienda. El 5 de octubre de 1768 se fugó y obtuvo el rescripto el 29 de ese mismo mes y año ${ }^{30}$.

\section{El contexto histórico de los diarios de los padres andaluces}

No podemos olvidar, a la hora de presentar estos diarios, el contexto histórico en el que se encuadran los hechos relatados en sus páginas. Tarea que por fuerza a de resultar sintética. El marco estricto de los acontecimientos se sitúa entre el 1 y 2 de abril de 1767, fechas en que los jesuitas fueron apresados en sus casas y colcgios, y el 14 de julio del mismo año, momento en que los religiosos de la Provincia de Andalucía arribaron a la isla de Córcega, lugar que se consideraba como punto final de su viaje y el más idóneo para su confinamiento. Este espacio temporal se encuentra, no obstante, jalonado por una serie de sucesos que resulta imprescindible recordar para un conocimiento más cabal del estado de ánimo y la índole de las anotaciones que plasmaron los diaristas en sus escritos.

El propósito inicial de Carlos III de enviarlos a los Estados Pontificios - idea que prevaleció entre el 1 de abril y el 28 del mismo mes, cuando los jesuitas recorrían la geografía española con rumbo a los puertos donde debían ser embarcados - chocó con la negativa de Clemente XIII a recibirlos en sus territorios ${ }^{31}$. Este obstáculo, ines- 
perado hasta cierto punto, aceleró los resortes de la diplomacia española y alteró, en alguna medida, los planes logísticos previstos para el cuidado y atención de los expulsos a lo largo de una navegación que se suponía breve y, sin duda, menos conflictiva.

Los esfuerzos diplomáticos se encaminaron a partir del 28 de abril hacia la búsqueda de un nuevo destino para los jesuitas. Y aunque, pronto, en las altas esferas del gobierno apareció como plausible la posibilidad de confinarlos en la isla de Córcega, lás negociaciones a dos bandas con la República de Génova -soberana de la isla- y con Francia -que auxiliaba a $a^{32}$ Génova en calidad de potencia protectora contra la rebelión de los corsos al mando de Paoli-, dilataron la decisión final de aceptarlos en territorio insular. Génova no dió su visto bueno a la solicitud española sino hasta los dias comprendidos entre el 12 y el 15 de mayo, ${ }^{33}$ y Francia, debido a las objeciones puestas por el comandante francés en Bastia, conde de Marbeuf, no hizo lo propio sino hasta primeros del mes de julio ${ }^{34}$.

El resultado de tales inconvenientes se plasmó en un hecho irreparable: cl convoy de los jesuitas andaluces -como lo habían hecho dias antes sus correligionarios de las Provincias de Aragón y Toledo-, partió del Puerto de Santa María el 4 de mayo con el convencimiento de que su destino era Civitavecchia y que los Estados Pontificios eran el lugar donde los religiosos debían planificar su futuro. Sólo cuando arribaron a dicho puerto el 30 de mayo, tanto el comandante del convoy, Juan Manuel Lombardón, como sus atribulados pasajeros supieron de la negativa del papa a recibirlos y de su nuevo punto de arribo: Córcega ${ }^{35}$. La noticia causó la decepción entre los jesuitas, pero tampoco satisfizo a los oficiales al mando del convoy que sabían de la escasez de los víveres para prolongar el viaje y de los problemas que iban a surgir con los patronos de algunas embarcaciones que lo integraban y que sólo habían firmado contrato para un trayecto hasta Italia ${ }^{36}$.

No acabaron aquí los problemas. Es en este punto donde entra en juego el exceso de celo del comandante francés en la isla, Marbeuf, y la cautela de su cortc. Tanto uno como otra temían que la presencia de un crecido número de jesuitas en los presidios corsos, dificultase el acomodo y la provisión de víveres para sus tropas. De ahí que la orden definitiva de París para aceptar a los regulares se dilatase hasta exasperar al gobierno españoli3. A to largo de todo el mes de junio los jesuitas andaluces, al igual que los de Aragón y Toledo que habían conocido antes el origen delínitivo de su desticrro, deambularon por el mar Tirreno costeando los parajes de Córcega ante la falta de órdenes precisas de Marbeuf para recibirlos. Pronto a estos tres convoyes, se Ies unicron en la espera los regulares de la Provincia de Castilla que habían partido con retraso desde el puerto del Ferrol el 24 de mayo. La escasez de víveres, el calor, los temporales, el cansancio y la desmoralización de las tripulaciones hicieron el resto.

Hasta el 14 de julio los jesuitas andaluces no pudieron desembarcar en el puerto de Calvi. El desembarco se hizo posible gracias a la decisión de Francia de desalojar sus guarniciones en los presidios de la costa occidental (Ajaccio, Algaiola, Calvi y Bonifacio), sustituyéndoles por un pequeño contingente de tropa genovesa ${ }^{38}$. Esta 
estrategia soliviantó a los corsos partidarios de Paoli que, al ver marchar a los franceses, artífices hasta el momento de una tensa tregua, decidieron poner sitio a las principales ciudades portuarias ${ }^{39}$. Tal circunstancia agravó todavía más la situación de los expulsos andaluces, cuyo desembarco en Calvi y Algaiola coincidió, precisamente, con las primeras escaramuzas entre los rebeldes corsos y las tropas de la República de Génova. A la reputación de isla inhóspita, carente de recursos, alejada del mundo, se unía, como colmo de las desgracias, el estado de guerra incipiente. Una guerra de escaramuzas, es cierto, que presidiría los primeros momentos del establecimiento de los jesuitas en la isla, mientras trataban de buscar viviendas para alojarse y de conseguir los primeros víveres. No puede extrañarnos, a la luz de lo descrito, y cuanto el lector puede consultar en los diarios, que la moral de los regulares comenzase a resquebrajarse al tiempo que aparecían los primeros síntomas de insolidaridad entre sus miembros dando lugar a las primeras deserciones para alcanzar la secularización 40 .

Si estos son, en apretada síntesis, los jalones políticos que marcan el contexto de los tres primeros diarios, no podemos olvidar tampoco otras circunstancias: las relativas a paliar los inconvenientes derivados del rechazo de Clemente XIII a aceptar a los jesuitas en los Estados Pontificios. El gobierno de Madrid, a través del Consejo Extraordinario, resolvió el 3 de junio de 1767, enviar una serie de comisarios a Génova y la isla para que se ocupasen de proveer de víveres a los expulsos, asegurarles la percepción de sus pensiones y evitar, en la medida de lo posible, los conflictos que la presencia de los religiosos pudieran ocasionar a Génova o a los corsos. ${ }^{41}$ Los primeros comisarios, Gerónimo Gnecco y su hijo Luis Gnecco, partieron inmediatamente hacia la isla, de tal manera que el 14 de julio estaban en Calvi asistiendo al desembarco de los jesuitas andaluces con las primeras provisiones de alimentos ${ }^{42}$.

A esta decisión del Consejo Extraordinario siguió otra del 6 de julio decidiendo incrementar la red de oficiales de la monarquía destinada a controlar y atender a los jesuitas exiliados. D. Pedro de la Forcada y D. Fernando Coronel, con rango superior a los Gnecco, fueron destinados a Córcega para supervisar la labor de los primeros y ocuparse de modo prioritario del pago de las pensiones. ${ }^{43} \mathrm{Su}$ llegada a Córcega tuvo lugar el 5 de noviembre, precisamente a bordo del mismo convoy en el que viajaba el P. Alonso Cano junto al resto de jesuitas procuradores de los colegios, y que había partido del puerto de Cartagena el 6 de octubre. Se trataba ya de un viaje para estos jesuitas menos crispado que el realizado por sus compañeros en la primavera anterior. La incertidumbre, la sensación de pérdida y desamparo que había prevalecido en las primeras expediciones, no era ya la nota dominante de los exiliados como se refleja en las páginas de este diarista. Los religiosos del convoy "de los procuradores" conocían ya su destino de Córcega y el sólo termor — además del abandono de la patria y la lamilia quizá para siempre - era el de confirmar con sus propios ojos las oscuras noticias que se habían filtrado acerca del cstado y situación de la isla; una isla, que por todos los indicios, había sido puesta en el mar y en la historia para hacer más amargos todos los exilios. 


\section{DIARIO DE LA NAVEGACION DE LOS JESUITAS DE LA PROVINCIA DE ANDALUCIA DESDE EL. PUERTO DE SANTA MARIA Y MALAGA HAS- TA CIVITAVECHIA}

\section{Diego de TIENDA S.I.}

Día 2 de Mayo de este año de 1767 se publicó por la mañana vando en dha. Ciudad del Puerto, prohiviendo que a la tarde se concurriesse a la Playa. A las 3 de la tarde salió de los Quartcles un trozo de Cavalleria, que se apostó en todas las bocas calles que daban en el Hospicio de Indias, y en todas las abenidas que miraban a el Muelle, apartando quanta gente encontraron. Desde dicha ora se comenzaron a embarcar los colchones, y baules en que iba la ropa de dichos P.P. A las 5 salieron de dicho Hospicio con escolta de soldados, los 154 Jesuitas que aquella tarde se embarcaron; es a saber: todos los Jesuitas de los Colegios de Sevilla, ${ }^{44}$ y los de los Colegios de Jaen, Antequera, Ubeda y Trigueros, a excepción de los Procuradores o Rectores, que quedaron para dar quentas, y de algunos otros que quedaron por enfermos. De camino passaron por la casa en que estaban los Jesuitas de Córdova, Frejenal, Higuera, Andújar, con los de otros tres Colegios de la Provincia de Toledo, que eran Cázeres, Llerena, Placencia, y Badajoz, a quienes vieron aunque de lejos con mucho consuelo, esperando el mismo destino. Llegados al muelle se repartieron en nueve barcos grandes, que inmediatamente se hizieron a la vela; dentro de una hora llegaron al sitio de la Bahía de Cádiz en donde estaban tres Navíos Succos Ilamados el General Wan Faulharg, el Bolsholme, 45 y la Paz. El primero de éstos era el destinado para esta primera divición de Jesuitas, quienes inmediatamente se transbordaron a dicho Navío en donde fueron recibidos del Capitán de Fregata D. Pedro Lombardón ${ }^{46}$ que havía passado a bordo a este Navío del suyo de la Princesa que mandaba, y en que nos havía de comboyar. Leidos los nombres de todos por el Comisario D. Francisco Saravia, ${ }^{47}$ se reliró a su Navío de Guerra y nosotros quedamos en el nuestro, vajo el cargo de un Piloto Español, y al cuidado del Capitán Sueco D. Carlos Magnus Stolpe.

Día 3 a la 1 de la noche hizo el Navío la Princesa con un tiro de cañón, la scñal de salir de la Bahía y a aquella hora comenzamos a levar anclas, y después caminar. A las 7 de la mañana, haviendo salido a las Playas de Sta. María, fuera ya de Cádiz, se dijo Missa el día de la Cruz. Aquel mismo dia por la mañana acabaron de llegr al Puerto los Jesuitas que se havían juntado en Jérez; y a la tarde, del mismo modo que el día antes, se hizo cl cmbarco de estos y los demás que estaban en el Puerto en los dos Navíos Suecos que quedaron en Ia Bahía; los Jesuitas de los Colegios de Córdova, Extremadura, y otros en el Bolsholme, y los de Cádiz, Marchena, Bacza, Jérez, Baena, y otros, en la Paz, en el uno 153, y en el otro 152.

Día 4 a la madrugada comenzaron a salir de la Bahía estos dos Navíos para juntarse con cl otro Sueco, y el de Guerra que estaba en las Playas de Sta. María. Con ellos se incorporó un Navio Veneciano que llebava el mismo rumbo. A las 7 de la mañana hizo la Comandanta señal de salir de las Playas de Sta. María con segundo cañonazo, y comenzó a andar con el Navío Succo el General con quienes a las 11 de la mañana se juntaron los otros dos Succos del comboy y el Veneciano. A la tarde nos quedamos en calma hasta las 12.

Día 5 , desde las 12 de la noche se levantó un viento mui recio, que pusso al mar en mucha agitación, y al Navío en mucho balanzeo. Con csto nos alemorizamos muchos, casi todos sc marearon, y passaron toda la madrugada, y parte de la mañana bomitando; y pocos comieron con sosiego, y varios nada. De 10 a 12 amainó, y calmó a las 12 . A las 6 de la tarde comenzó a soplar viento favorable para entrar por el estrecho; hizo señal de caminar hazia él 
Ia Capitana, y a las 8 de la noche llegamos a Cabo Espartel, desde donde nos apartamos de la Capitana que quedó atrás con el Navío $l a$ Paz.

Día 6 a las 3 de la madrugada nos juntamos con la Capitna, y el otro la Paz, haviendo caminado por la Costa de Africa tan cerca de tierra, que el Capitán y Piloto oían las voces de los Moros; el otro Navío Sueco se havía adelantado a todos al entrar en el Estrecho. Desde las 4 de la mañana avistamos a Tarifa, y Punta de Tierra de España, que con la de Africa forma el Estrecho. Después por el aire contrario huvimos de dar muchos bordos, en los quales fuimos observando a veces a quarto de legua de distancia las Costas de Africa, y los sembrados de los moros, y empezamos a divizar a Zeuta y Gibraltar, con su Bahía y la de Algeciras, a las 5 nos entró viento favorable, y a las 7 passamos de Gibraltar dejando el Peñón a nra. izquierda. Aquél día llovió, y nos incomodó mucho.

Día 7 desde las 12 de la madrugada nos entró viento Nordoueste, conque seguimos favorablemente. A las 4 la Capitana disparando dos tiros, y poniendo cinco froles, nos hizo señal de estar a la Capa, por no saber el parage en que estábamos, a poco hizo señal de marchar, y a las 7 de la mañana avistamos el Castillo de Fuengirola y Torre Molinos, junto a Málaga, y aquí se juntaron todos los Navíos; a las 11 dimos fondo en la Bahía de Málaga a media legua de dicha Ciudad hechando el áncora. Al llegar hizo salva la Capitana con 9 tiros, a que respondió la Plaza con 5. Todo aquel día estubimos con anteojos observando los edificios de la Ciudad, de donde eran algunos de los que venían; aquella tarde a las 6 se embarcaron los jesuitas de Andalucía que se havían juntado en aquel Colegio, ${ }^{48}$ en cinco vasos; a saber: el P. Provincial, Colegio de Santiago y varios Sacerdotes, Estudiantes, y Coadjutores hasta 32 en un Navío Inglés; el P. Rector de Granada con varios otros hasta 32 en otro Francés; el P. Rector de Málaga con otros 35 en uno Olandés; el Rector de Loja con otros 19 en un Barco Longo de Málaga; y el P. Rector de Guadix con otros 25 en una Saetía Malagueña; ${ }^{49}$ desde nuestros Navíos vimos la mucha gente que salió a ver el embarco. Aquí no se nos permitió traer de la Ciudad algunas cosas que se necessitaban para algún alivio de varios enfermos, endebles, ancianos, que las querían comprar por su dinero. Sólo sí se nos trageron por quenta del Comisario algunas hogazas de pan, y alguna porción de lechugas, y ccbollas para refrezco, porque ya iba consumido lo que sacamos de Cádiz.

Día 8 a las 9 de la mañana disparó la capitana la tercera pieza de leva, y empezamos a caminar todas las embarcaciones en número de 10 . A las 12 nos entró calma, y quedamos a vista de Málaga, toda aquella tarde y noche.

Día 9 a las 8 corrió algún levante y empezamos a caminar; y oy haviéndose acabado el pan duro, comenzamos a comer viscocho o galleta. Después huvo calma a vista aún de Málaga, a la tarde a las 2 bolvió algún viento y bolvimos a caminar algo aquella tarde y noche.

Día 10, casi no huvo viento por la mañana; a las 11 avistamos a Sierra Nevada. A la tarde a las 5 con poco viento llegamos frente a Bélezma, y Castillo de Ferro en las Costas de España; haviendo avistado antes tres embarcaciones, que temimos ser Argelinas, y más, al observar, que la Capitana abrió todas las compuertas de los cañones. Toda aquella noche estuvo el viento en calma.

Día 11, a las 6 de la mañana entró Levante recio, que nos forzó a dar muchos bordos; desde las 5 de la tarde por toda aquella noche calmó, estando a vista de Adra.

Día 12, a las 5 de la mañana nos hallamos otra vez a vista de Castil de Ferro. Desde las 6 se levantó otra vez cl Levante recio, y bolvimos otra vez a andar bordeando hasta las 12 que calmó; a las 2 de la tarde se levantó un Norueste, conque seguimos ya derechos nuestro rumbo, aunque no mui deprisa, y avistamos la Ysla de Arbolán. A las 7 se bolvió a Levante, aunque calmó presto. 
Día 13 repitió el Levante hasta las 9 de la mañana que se mudó al Sudoeste, y seguimos siempre a vista aún de Sierra Nevada. A las 12 se bolvió en Poniente corto, que arreció al anocheser, y con él caminamos toda la noche. Este día por especial favor trajo el Comisario algunos panecitos para los ancianos y enfermos, pues la galleta aún los buenos no podíamos passarla por insulsa, sin sal, y aunque blanca tan dura, que era necessario partirla contra las tablas.

Día 14, amaneció con nubes, y Poniente más recio, conque seguimos a toda vela; a las 11 avistamos el Cabo de Sacratif, y entonzes la Capitana nos mandó acercar, por haver visto un Navío que no conocía, y embió a reconocer. Esta tarde hablamos con el Navío en que venían los P.P. de Cádiz, y otros ya dichos.

Día 15, viernes, nos hallamos con el mismo viento delante de Vera, haviendo passado aquella noche cl Cabo de Gata. A las 8 de la mañana se mudó en Norte que duró todo el día; a la noche se cambió en Poniente, que a media noche calmó y quedamos los del Navio el General sin poder seguir a la Capitana, por estar metido en unas corrientes en que no governaba el timón.

Día 16, amanccimos en calma, con tantos balanzes del Navio, que desde las 2 de la madrugada hasta las 12 de la noche siguiente todos, o los más estuvieron mareados, y varios bomitaron.

Día 17, a la 1 de la noche entró Levante, conque andubimos bordeando; a las 7 ya enfrente de Cartagena avistamos 10 velas puestas en linea a nuestra izquierda; inmediatamente passó la Capitana señal de acercarnos a recibir órdenes, y sospechoso el Comandante de que eran Moros hechó vandera Inglesa para no declararse, esperando la señal que ponían los otros. Estos hecharon vandera Inglesa en la embarcación principal, y en otras, y Olandesa en otras, receloso aún el Capitán de la Comandanta, determinó que los Navíos nuestros del comboi se dirigiessen en derechura a guarecerse en Cartagena, distante 4 o 5 leguas, mientras él iba a dar caza. Para esto hizo que dos oficiales de su Navio passasen a la Sactía Malagueña, y en ella fuessen a reconocer la embarcación principal avistada. Dichos oficiales abordaron a clla, y reconocida hizieron señal mandando poner vandera española en su Saetía, con la que la Capitana se asseguró y correspondió con vandera Española, era comboy de Navíos mercantes, y assí salimos de susto; más en todo esto se gastó aquella mañana y perdimos el vicnto que calmó a las 12 . Aquella tarde a las 4 vimos la entrada del Puerto de Cartagena a distancia no larga.

Día 18, a la una de la noche pusso la Capitana en el Arbol mayor un farol cn señal de cnemigos, que quitó a las 2. A las 5 entró viento de Poniente que calmó casi a las 8 . A las 12 comenzó otra vez algo recio y seguimos frente de Cartagena. Este día se juntaron a nosotros de varios rumbos otras 10 embarcaciones que hacían vistoso el mar, a quienes nra. Capitana puso su vandera, y se separaron a la tarde, a la Oración casi calmó el Poniente, haviendo llegado al frente de Cabo de Palos.

Día 19, amanecimos en calma y balanzes, a las 8 entró Sudoeste y empezamos a caminar despacio por no tener viento la Capitana que se atrasó para tomar altura; a las 5 de la tarde avistamos el Trimnfante, ${ }^{50}$ Navío de Guerra Español que venía de Barcelona, y puso al principio gallardete español, a las 6, ya más cerca, puso vandera Española, con la que correspondió nuestra Capitana, y los demás con las de sus Navíos; al pasar junto a nosotros a tiro de fuzil, nos habló el Capitán, desseando a los R.R.P.P. Jesuitas feliz viage. El viento siguió aquella noche.

Día 20, a las 7 de la mañana apretó, y a las 9 passamos junto a un Navio de Guerra Portugués, que venía de Génova a Portugal nuevamente comprado; nos saludó con menos demostraciones que el Triunfante. A las 12 se mudó el viento en sudocste, y casi Poniente recio, con nubes, que siguió toda la tarde; en ella hecharon los Pilotos varias vezes la corre- 
dera, y la última conocieron que andaba el Navío casi 6 millas por hora; a las 7 apretó de modo que según la corredera se andaban 7 millas por hora; a las 10 amainó y quedó el Navío en grandes balanzes por toda la noche. Este día nos visitó en el Serení del Navío de Guerra, el Comisario Sarabia, ${ }^{51}$ a quien acompañó D. Francisco de Cárdenas, Mayordomo del Navío de Guerra, para ver a varios Jesuitas conocidos suyos, quando se criaba en cassa del Marqués de Thous, en Sevilla.

Día 21 , a las 3 de la madrugada bolvió el viento y comenzamos a andar hechando más vela, a las 9 avistamos un Navío Sueco que venía hacia el Estrecho, a las 2 de la tarde se cambió el viento en Sur; a las 7 comenzaron las embarcaciones a hacer rizos, para csperar al Navío Francés atrasado mucho y assí seguimos toda la noche.

Día 22, a las 3 de la madrugada se cambió en Poniente largo, conque anduvimos a 2 leguas por hora; a las 12 se observó por los Pilotos que estábamos en 38 grados de Latitud, y que en la singladura desde las 12 del medio antezedente, se havían andado 40 leguas; a las 6 de la tarde salimos del Golfo de León, y nos hallamos en el de Bugia, y vertientes de San Andrés, a 20 leguas de Menorca, a las 10 calmó enteramente el viento, y quedamos en grandes valanzes toda la noche, que muchos passaron sin dormir, y asustados.

Día 23, amanecimos en la misma calma, y balanzes mayores que nunca, de modo que ni estar en pie se podía por los baivenes y mareos que nos fatigaron muchos más que nunca hasta aquel día, a las 4 de la tarde por fin entró Sur, nos aliviamos y empezamos a andar casi 5 millas por hora, a las 6 se mudó en Sueste quarta al Leste, y aquella noche siguió poco fuerte.

Día 24, amanecimos con el mismo viento y seguimos poco a poco, a las 12 según los Pilotos nos faltaban 20 leguas para la Isla de San Pedro, cercana a Cerdeña; a la tarde nos entró algo más recio con Agua y con Nubes, a las 6 hizo la Capitana que la Saetía Malagueña se adelantase a explorar tierra, y avisase con tiempo, y los demás la seguimos.

Día 25, después de las 12 de la noche empezó a llover, y hazer relámpagos, entonces la Capitana, con tres faroles y un cañonazo, hizo señal de estar a la capa y a poco pusso otra señal, para que todos los Navíos del Comboy pusiessen farol para que se conociessen; a las 3 , el Capitán del Navio Sueco el General en que iban los Jesuitas de Sevilla, descubrió la Tierra y Costas de Cerdeña antes que ninguno; mandó poner en su Navio señal de tierra hechando vandera Sueca; con lo que inmediatamente la puso también la Capitana poniendo la vandera Española, y a poco llegó de buelta la Saetía, e hizo señal de tierra disparando un cañonazo. Assí logramos los Jesuitas extrañados, y desterrados a Italia, descubrir la primera tierra de Italia en el mismo día en que la Iglesia celebra a San Gregorio Papa VII, que murió desterrado en Salerno de Italia por la defensa de la Iglesia. A las 8 de la mañana entró un Norte mui recio, que al principio nos asustó mucho, con el que empezamos a doblar los Cabos de Cerdeña caminando mucho; después amainó hasta que a las 6 de la tarde juntándose con nubes apretó tanto que al navío le llevaba volando, y a orça con gran presipitación, lo que a muchos consternó singularmente hasta las 10 de la noche en que calmó el viento, y cessó el Agua que por mucho ticmpo le acompañó; aunque quedó el tiempo levantado y amenazando tormenta, por varios relámpagos que hacían no mui lejos de nosotros; si bien Dios quiso que todo se disipasse de suerte, que a las 12 de la noche hizo la Capitana señal de estar a la capa, como se estubo hasta las 4 de la madrugada siguiente.

Día 26, desde las 5 de la mañana se comenzó a andar con el tal qual Nonte que corría. Doblado ya el Cabo Carbonel, aquella noche, y haviendo antes aquella tarde passado el Puerto de Callèr, a las 11 de la mañana de repente se arrojó sobre nosotros un torvellino de Agua y Aire Norte que empezó por truenos y que hizo nuevamente consternar a los no acostumbrados a Borrascas de Mar; pero quiso Dios que al quarto de hora calmasse el aire, y se relirasse la 
Nube quedando casi parado el Navío. Aquella tarde a las 7 llegó un criado del Comandante en el Sereni de la Capitana, con un papel que era Instrucción del modo con que hemos de hazer el desembarco. Según él, los tres Navíos Suecos serán los primeros a desembarcar los Jesuitas, que juntándose en la Playa esperarán allí quien les diga el rumbo que han de tomar, y destino a que se han de dirigir, de éste no sabemos nada, tal vez se sabrá más bien por España a estas horas, y no podrá ir en este Diario. Esta noche estubo cl viento en calma.

Día 27 siguió la calma hasta las 11 de la mañana que entró Poniente bueno, y seguimos a 5 millas por hora, hasta las 8 de la noche que calmó; a las 10 , de repente se levanto un torbellino de viento que duró por media hora, trayendo a las velas, Navío, y nosotros cn mucha consternación, a la media hora se fijó en viento tormentoso Nordeste tan recio, y impetuoso, que puso al Mar en notable agitación de olas, y al Navío en unos balanzes mayores que nunca, lo que duró toda la noche sin cessar; teniendo a todos en mucho susto, y varios sin pegar los ojos en toda la noche.

Día 28, el torvellino de viento duró hasta las 8, y los balanes del Navío siguieron hasta medio día en tanto excesso que no pudimos tener el consuelo de oir Missa este día de la Assención, por no ser humanamente posible; a las 3 de la tarde entró Poniente que duró hasta las 8 , y seguimos estando al fin a 4 leguas de Civitavechia, a las 9 se levantó una tormenta de Nubes y vientos Nordeste cerca del Golfo de Bonifacio, la mayor que havíamos tenido, y que en realidad fue cruel, y nos asustó aún a los menos aprehensivos, se juntó con las mayores agitaciones de la Mar, y balanzes del Navío, cercados por todas partes de Nubes, que a veces despedían bastante lluvia, siendo lo más horroroso en el silencio de la noche, los notables baivenes del Navío, y los golpes de agua que las olas del mar sacudían contra él con un ímpetu y fragor, scmejante al de un cañonazo; todo esto duró toda aquella noche, que el Señor quiso darnos tan hermosa por ser de Assención, con más consternación que nunca, de todos los más animosos; la que se aumentó quando a las 4 de la siguiente mañana, comenzó el Mar a arrojar golpes de Agua dentro del mismo Navío, que con ser el que iban los Jesuitas de Scvilla como una Fragata de 40, lo veíamos caminar con horror debajo de las olas del Mar, que como arco saltaban por él, y sobre él; a todos nos metieron en escotillón; y los que quisieron animarse a salir fucra sc marcaron y bomitaron más que nunca. Aquella tarde acercándose a nosotros la Comandanta, se informó de nro. Piloto sobre el modo de entrar en cl puerto.

Día 29, duró la tormenta y susto hasta las 12 , en que Dios quiso que cessase lo recio; y a aquella hora puso la Capitana señal de haver descubierto tierra de Italia, y a las 4 llegamos a 2 leguas de ella; pero a las 4 nos vino por el frente otra tormenta de agua y aire, que al principio temimos ser de Rayos y Truenos, más quiso Dios éstos no los huviesse, o no se sinticsen; con todo al instante hizo el Capitán que todos los que havían subido, bajaran al cscotillón, y desembarassasen para las maniobras. La prontitud y destreza en esta prebención hizo que la fucrza del uracán acompañado del agua no hiziesse peligrar al Navío, pero ínterin nosotros metidos en nras. camas vajo de cubierta estubimos pasando nro. susto que duró hasta la media noche en que cedió la fucrza del aire. Este día no se pudo comer en mesa, si es que huvo quicn tubiese gana con los marcos y sobresaltos continuos, nacidos de oir el bramido espantoso del mar y sus olas, los golpes de éstas al Navío, y sobre él, que cada movimiento parecía caer de Iado; gracias a Dios que en este viernes en que avistamos la Italia, destinada a nro. destierro en otro Vicrnes, nos quiso dar cste día de Passión.

Día 30, Sábado, de San Fernando, en que cumplian 9 scmanas de nro. embarco, a la media noche hizo señal la Capitana de virar hacia el puerto, retirándonos del mar en donde dos havíamos enmarado huyendo de la tormenta que nos havían venido a las 4 de la tarde antes. Todo el día estuvimos caminando hacia tierra, y a las 4 de la tarde puso la Capitana scñal de 
despedida, con lo que el Navio Sueco el General se dirigió hacia la entrada del Puerto para anclar en él esta noche, y la Capitana se quedó en el mar.

Ultimamente esta noche a las 9 se determinó el dho. Navío el General a entrar en el puerto de Civitavechia, como de hecho entró a remolco de su lancha, y lograron los Jesuitas que venían a su bordo de Sevilla el tocar este puerto, y tierra primera de Italia sábado 30 de Mayo a las 10 de la noche por el reloj de España, y a las 3 por el de Italia. En él encontraron ya al Navío Succo la Paz, y al Inglés, y Olandez; de los demás barcos no sabemos a la hora que esto se escribe, a vordo del general Van Faulbarg, oy Domingo 31 de Mayo.

\section{NOTAS}

1.- Todo este negocio se ha comenzado, continuado, y seguido en día de viernes, por lo que haze a sus principales passos. En Viernes de Passión lue la intimación del extrañamiento de los Jesuitas en Sevilla, y toda Andalucía. Viernes de Dolores fue la salida de estos de Sevilla. Vicrnes Santo, la intimación a los Coadjutores, si querían quedarse. Víspera de la Cruz se embarcó. Viernes 29 de mayo avistaron a Civitavechia. Viernes 10 de Julio, la noticia última de su desembarco en la infeliz Córcega.

2.- Aunque las Proviciones hechas por el Comisario D. Francisco Saravia han sido abundantes en todo por Orden del Sr. Arriaga, Secretario de Marina en carta al Intendente de Cádiz, ordenándole que en todo dispusiese el viage en la inteligencia, de que en cada jesuita iba su Persona propia, señalando por el Rey $7 \mathrm{rls}$. por día para el plato de cada individuo ${ }^{52}$ con todo, no ha dejado de haver mucho que tolerar y ofrecer a Dios en la extrechez, estando por ejemplo los 154 Jesuitas que venían de Sevilla en el General Van Kaulbarg 35 passos de largo i5 de ancho y dos varas de alto, puestos los sitios de las camas como andén de gusanos de seda, en la calidad y hora de la comida; en el desaseo indispensable en tan poco sitio para tantos, causa de plaga de animalillos, que a poco se extendió por todos, finalmente, en otras mil cosas que se omiten, y sólo se dejan a Dios para que las sepa para promiarlas.

3.- Al fin ya todos llegaron a mucho desaseamiento en lo natural; con todo, todos se han mantenido fuertes en el ánimo, y Dios les continua el favor de mantenerlos con robustez suliciente para los nuevos trabajos que esperan en ia tierra de su destierro, extraña, y en donde sólo tienen a Dios que los asista sin otro arrimo y ánimo en lo humano; pero con gran confianza en el Sr. mismo, que como los animó y esforzó para comenzar el Sacrilicio, los vigorizará y esforzará para consumarlo a gloria suya para los fines ocultos de su altíssima Providencia, que en todo, y por todo veneran, y dessea sea glorificada.

4.- Los Jesuitas que han quedado por ancianos o enfermos en España son: de Sevilla,P. Domingo Garzía, P. Luis Valderas, P. Juan Maestre, Ho. Pedro Espejo, Ho. Miguel de Tovar; de Córdova, P. Francisco Ruano, y el Ho. Gregorio Alvarez, que murió en Ezija; de Granada, Ho. Hinojosa, Ho. Fernando de Flores, Ho. Alonso de Vargas; de Cádiz, P. Gaspar Diaz; de Montilla, P. Andrés Ramos; de Ezija,P. Tena; de Baena, José Marquéz; de la Higuera, P. Gregorio Tovar, de Frejenal, P. Joseph Maraver; del Puerto., P. Miguel del Puerto, P. Marcos Esuzia, P. Villarreal, de Utrera, P. Francisco Baena, P. Pedro Pacheco, Ho. Pedro Gutierrez; de Antequera, P. Juan de Blancas Rector, P. Antonio Santisteban, P. Francisco Béjar, P. Pedro Vizente, P. Joaquin de Azevedo; de Osuna, P. Antonio de Flores, P. Cortés, de Ubeda, P. Juan de Gamia; de Sanlucar,P. Francisco Morán. 


\section{CONTINUACION DEL DIARIO DEL VIAJE DE LOS JESUITAS DE ANDA- LUCIA, DESDE CIVITAVECHIA 31 DE MAYO DE 1767.}

Este día por la mañana a las 8, quando creíamos estar de lirme ya en el Estado Eclesiástico, y hechos los líos de ropa para desembarcar tubimos de repente noticial de que teníamos que volvernos por haver Orn. de Su Santidad de que no saltasscmos a tierra ningún Jesuita, aunque se nos permitía se nos assitiesse con refrescos que necesitassemos, y que pudiesen salir a tierra los seglares que venían en nuestros Navíos. Al liempo mismo se supo que esta fortuna havían corrido los Jesuitas de Toledo y Aragón, que sucessivamente antes que nosotros havían arrivado, ${ }^{53}$ y después de pocos días havían buelto a hacerse a la vela hacia Poniente, sin saberse de cierto a donde. Díjose que Su Santidad no nos admitía por la carestía y falta de víveres de sus Estados, y que esta era la respuesta que havía dado al Rey de España, excusándose de ello, con que nos hallamos con el desconsuelo que se puede inferir, de vernos sin hallar un palmo de ticrra en que fijar pie, bolviendo a tener que hacer nuevo sacrificio a Dios de nostros en este total desamparo y abandono de las criaturas, que nos dejaban a sola la providencia de Dios por estos mares, sin saber qual havía de ser nuestro paradero.

Día 1 de Junio. Este día continuamos anclados en el puerto, en la misma indecisión y duda de nro. paradero; nos vissitaron varios sugetos de distinción en el pueblo, de quicnes oimos las noticias que corrían en Italia sobre las cosas de los Jesuitas, y miedos de que despućs de los españoles se sigan los napolitanos, alemanes, etc., a venir desterrados al Estado Eclesiástico.

Día 2. Se recibieron varias cartas de Roma, por las quales supimos que N.P.General tenía entendido del Papa que havíamos de ir a vivir a la Isla de Córcega a unos villages, o aldeas que la República de Génova tiene allí (dizen que en número de 12 , de las que bendrán a caber tres a la Provincia de Andalucía). De hecho supimos que los Jesuitas de Toledo y Aragón, que havían Ilegado antes que nosotros a Civitavechia, haviendo retrocedido de On. del Ministro de España en Roma hacia Córcega, aunque a principio havían sido despedidos, o impedidos de descmbarcar por el Comandante de las tropas francesas, que en número de 2.500 tienen en aquelios lugares de guarnición el Rey de Francia, por fin havían sido recibidos y desembarcados allí. Las mismas cartas añaden que nada se traspirava deste negocio, que unicamente se manejaba por S. Santidad y el Rey de España. Que N.P. General havía prohivido a los Jesuitas hablar de este negocio que se miraba como de Estado, y que la misma prohivición havía puesto el Papa en Roma, con pena de 5 años de Galeras. Que Su Santidad y toda Roma estaba summamente condolida de la suerte de los Jesuitas Españoles, no menor que lo quedó Sevilla y loda España. Que cra tanta la cautela con que en este se procedía, que al P. Asistente de España Francisco Montes, por dos veces se le negó la licencia que pidió, para venir a Civitavechia a ver a los Jesuitas de Andalucía, por ser de su Provincia. Aquella tarde bino a bordo del Navío el General el Comisario D. Francisco Saravia, de quien al vernos, enternecido y casi lloroso, oimos por modo de consuelo, que Dios nos quería mucho, que quería probássemos el Cáliz. hasta lo último; que según las instrucciones que tenía el Comandante havianos de bolver a hacemos a la vela, y andar inciertos por esos mares hasta que Su Magestad determinasse el lérmino de nro. destino. Con lo que huvimos de bolver a hacer nueva entrega a Dios de nosotros para quanto su amorosa Providencia dispusiesse de éstos sus desterrados infelizes Jesuitas entregada en sus brazos, y únicamente pendientes de sus altas disposiciones. El mismo comisario al despedirse se llevó a tierra a tres de los Jesuitas de este Navío que estaban incapazes de seguir en él por enfermos gravemente, y los puso en el Hospital de San Juan de Dios, uno cra Sacerdote; otro Estudiante, otro Coadjutor. Quienes al despedirse nos dejaron mui condolidos, por el recelo de no haver de bolverlos tal vez a ver más en esta vida. 
Día 3, supimos que en Italia corrían impresas las Instrucciones que en España se formaron para la ejecución de nuestro extrañamiento, y aún varias otras piezas concernientes, como el Interrogatorio a los Procuradores sobre qué Letras de cambio teniamos, quánto se les embiava a N.P. General para su carroza, y gasto, etc.. Entre estas piezas una cra cl tanto de la Carta del Rey de España a Su Santidad, fecha en 31 de Marzo (en cuya noche se ejecutó el Decreto en Madrid), en la que en sustancia se dize, que atendiendo a la interior paz, y tranquilidad de sus Estados, se ve en la precissión de extrañar de ellos a todos los Jesuitas que han tenido la suerte de nacer vasallos suyos, remitiendo a los Estados de Su Santidad, que como Padre universal los atenderá; a cuyo fin para no gravar el Erario Apostólico, les señala lo suliciente para su sustento. Lo que noticia a Su Santidad, esperando lo tenga a bien, etc. Al tiempo mismo supimos de cierto, que para la respuesta a esta Carta y resolución de el casso, tubo su Santidad Consistorio de todos los Cardenales el día 17 de Abril, precediendo dos dias de término para estudiar el punto. En dicho Consistorio se resolvió por casi todos los votos, que no se admitiesen los Jesuitas Españoles, no sólo por la carestía y falta de víveres, sino por el recelo de que falten los alimentos señalados por el Rey, por la cortapisa con que se señalan, y por el temor de que dentro de poco sigan (como se teme) este cjemplo los Reynos de Nápoles, Alemania, etc. Esta respuesta dejó a los Jesuitas Españoles, por una parte excluidos de su patria natural, y por otra sin recurso, ni assilo alguno en lo humano para buscar otra, no teniendo ya un palmo de tierra, no sólo para reclinar la cabeza, más ni aún para fijar el pie, sólo pendientes de la Divina Providencia, quando la humana por razones de Estado los dejó abandonada a su fortuna, en medio del mar, aunque a vista de la ticrra. Entonces fue quando de nuevo bendijeron la mano del Señor, que assí los afligía, mostrando en ello, que querían fiasen sólo en Dios, quando se vé́an enteramente, destituidos de todo humano arrimo, y entonces fue quando de nuevo repitieron el Sacrificio de su total entrega en manos del Señor, para que dispusiesse de ellos, según los fines de su amorosa Providencia, con una entera resignación y conformidad. Esta oferta, conformidad y resignación se confirmó más, quando al día 4 se supo de cierto, que aquél día nos hacíamos a la vela para Córcega; esta noticia nos la dio el Theniente de Navío D. Antonio de Ocarol, ${ }^{54}$ cordovés, que el día antes havía venido de Roma con instrucciones del Ministro de España, para quien havía sido despachado en Posta dos dias antes por el Cónsul de España en Civitavechia; el qual oficial aquella mañana bino a vordo del Navío el General y después de haver hecho transbordar a él 12 Jesuitas de los que venían en cl Navío Inglés (que lue despedido por hacer mucha agua) y repartidos los otros 23 que traía en el Navío la Paz, la Saetía, y Barco Longo de Málaga, hizo que el Navío el General, con un cañonazo, diesse a las 7 de la mañana la señal de la vela a los demás, haciendo de Comandanta por la Princesa, que por ser Navío grande no cabiendo en el Puerto de Civitavechía estaba dado fondo en el de Sto. Estéfano, algunas leguas distante. A la 1 del día hizo que con otro cañonazo se diese la señal de salir de la Bahía, y a poco rato ya fuera de ella, con el terzero, la de scguir cl rumbo hacia Sto. Estéfano a juntarse con la Capitana, y con el Navío Succo el Blestkolm, y el Olandés que estaban con ella por no haver podido entrar en el puerto de Civitavechia a causa de los vientos, quando entraron los demás. Toda aquella larde y noche caminamos con viento contrario Sureste sin adelantar casi nada, antes con el peligro de haver estado aquella noche a las 12 para naufragar todos, dando el Navío en tierra, y varando $\sin$ poderlo remediar, como huviera sucedido a no haver el Señor impedido que arreciasse el viento, que insensiblemente, nos iba arrojando a la tierra, e impeliendo hacia unas corrientes, de las quales no huviéramos podido salir sin estrellarnos hacia tierra. Pero gracias al Señor, que nos libró de este peligro, que estubieron recelando el Capitán y Píotos, sin decirnoslo hasta después de sucedido. 
Día 5, amanecimos a corta distancia de Civitavechia casi sin haver adelantado hacia Sto. Stephano por lo contrario del viento Sueste, que seguía, y siguió por todo el día ocacionando continuos y desmesurados balanzes del Navío, que sin embargo de haverse ya acostumbrado, movieron en muchos frequentes mareos, y vómitos en los más, con descomposición de cabeza que molestó mucho aún por la noche.

Día 6, amaneció del mismo modo el día, y el Navío en el mismo sitio, aunque ya con menos balances, pero sin adelantar hacia el rumbo, por lo que fue forzoso andarse dando bordos; a las 10 de la mañana declaró al Theniente D. Antonio Ocarol el Piloto práctico que havíamos sacado de Civitavechia, que no podíamos sin peligro passar la noche en aquellos mares por lo alterado de ellos, lo que tomado por certificación escrita y firmada, desistió dicho Theniente de la idea que tenía de esperar al Navío la $P a z$, antes de continuar el rumbo hacia la Capitana, y permitió que bordeando se caminase hacia St. Stephano, o hacia alguna ensenada, a favorecernos mientras la noche de lo alvorotado de aquellos mares, siendo aquí digno de no omitir el caimiento y aflicción que se apoderó de los ánimos de todos, especialmente de los más ancianos, a quienes era compassión verse por una parte en medio de estos mares, a quienes ya tres días estábamos experimentando enfurecidos y temibles, y por otra sin saber quando, ni cómo sería nro. arrivo que ya miravan todos como feliz en medio de ser a Córcega, una tierra a quien los mapas y Geographos hacen de aire grueso y poco sano, inculta, y sin aquellas providencias necessarias para la subsistencia aún en lo más preciso; a unos lugarcillos compuestos de casas de paja, y esos pocos por el número de soldados franceses que allí ai, y por el de los casi 3.000 Jesuitas que se les Ilegan; fronteros a las tierras de los rebeldes de Córcega que están en Guerra con la República de Génova, y que a pie llano podrán entrar quando quieran en nras. casas o casillas, y entrar a saco quanto tengamos; tierra fría, para cuio reparo no llevamos otro defensivo que el poco mueble de nuestra ropa, de la que el que más sólo trae la de vestirse, con su colchón y algún cobertor, sin más cortina, tablas, ni tarima, que sólo esperan sea cl suelo y las paredes. Bendito sea el Señor que assí lo dispone; su Magestad de fuerzas para ésto, y mucho más que aún esperamos padecer, sin otro consuelo, ni premio que el que esperamos en cl cielo de su mano. Tícra enteramente sin comercio con otras de Europa, por lo que ni esperamos tener en ella aquel consuelo que en otras del estado Eclesiástico de tener con quien tratar, por quien saber de nuestra España, y por quien los nuestros, o Padres, o Parientes, o Amigos sepan de nosotros, y por quien de ellos recibir algún socorro para las necesidades que forzosamente nos esperan, y en que sólo tendremos que esperar y levantar los ojos al cielo, de donde únicamente podremos recibir alivio, que no podrán darnos nrs. Padres, o Amigos por no poder embiarlo, ni tener por donde, o por no saber de nosotros, ni de nuestro paradero en esta tierra tan apartada de todo comercio, y puesta en medio de estos Mares; en la qual a más de lo dicho fuera de la notable incomodidad de vivir en casas o chozas infelizes de dos en dos, o quatro en quatro mal acomodados, tendremos el sinular desconsuelo de no haver de poder decir Missa los más de los Sacerdotes, por la falta de hornamentos que suponemos en una Iglesia de aldea, en que quando más abrá una Cruz, si lo ai. Pero a todo vamos dispuestos y conformes con la voluntad del Señor, que se contentará con la nuestra quando de ella no pueda el dejar de ofrecerle este culto, y sacrificio diario, por más que lo descemos.

Día 7 , nos amaneció a corta diferencia en el mismo parage, por que el Theniente no quiso que aquella noche se tomase puerto, ni nos acercásemos a la Capilana hasta que se juntasse a nosotros el Navio la Paz, el qual la tarde antes, junto con los dos vasos malagueños, con el temporal contrario se havían separado. Y assí passamos todo aquel día dando bordos en el Monte Argentaro, y el del Lirio, perteneciente al Duque de Toscana; y este día tubimos sentimiento por otra parte, llegando a recelar que nra. ida a Córcega era supuesta, y la verdad ol 
detenemos por estos mares esperando la resolución de Madrid. Con que quedamos por todas partes en indecisión y sentimiento por todas.

Día 8 , por lin después de varios bordos en el mismo sitio en que gastamos todo el día antecedente, haviéndose avistado a lo lejos $l a P a z$, mandó el Theniente virar hacia Sto. Stephano, y haviendo a las 10 de la mañana passado el Monte del Lirio, a las 2 de la tarde dimos fondo los que veníamos en el navío el General, y anclamos en el puerto de Sto. Stephano, que está enfrente de Orvitelo. Allí encontramos ancorados a la Capitana y los Navíos Francés, Olandés, y el Blestkolm, que no haviendo podido entrar en el pucrto de Civitavechia con los demás el 30 de mayo se retiraron a este puerto distante 15 leguas del de Civitavechia. Hallamos la novedad de saber que el día 6 se havían transbordado a la Capitana con todo su equipaje los 150 Jesuitas que venían en el Blestkolm por no haver querido su Capitán concertarse con el comandante en el precio por su transporte a Córcega. ${ }^{55}$ No ocurrió otra novedad en el día.

Día 9, oimos varias noticias, ya alegres, ya melancólicas, sobre nro. futuro destino, según unos, a Córcega; según otros, a España, ya dispersos, ya no dispersos. A la tarde a las 4 llegó y dió fondo el Navío la Paz, y a la noche salió de la Bahía el Blestkolm, y se hizo a la vela para Cerdeña, despedido del comboy. A las 11 con licencia del Comandante, bino a vernos un Jesuita de los que iban en la Capitana, por quien supimos las mismas noticias con el mismo fundamento.

Día 10, huvo en la Capitana junta de Pilotos sobre el puerto que se podía tomar en Córcega, y quedó resuelto que se dirigiese la proa a Ajacio, en caso de no poder arrivar a la Bastia, quedando determinada nra. salida para la mañana siguiente. En esta nos visitó un D. Joseph Gómez, Coronel de un Regimiento de Nápoles, Theniente de Rey, que es, de Orvitclo, Sto. Stephano, Puerto Hérculo, y Puerto Longón, pertenecientes al Rey de Nápoles en esta costa. Era natural de Sevilla, y estuvo informándose de varias cosas de ella en la conversación que tuvo con nosotros.

Día 11, por falta de viento no salimos del puerto. Aquella mañana supimos por un Maltés que sirve de correo para Córcega, que seis días antes havía venido de allá, como a su salida de allí aún estaban a vordo los Jesuitas que estaban en San Florenzio y la Bastia, aunque a los de ésta se les permitía entre día saltar en tierra. Esta tarde permitió el Comandante de la Capitana, que algunos jesuitas del Navío la Paz viniessen a ver a los de los otros Navíos, por quienes supimos la duda que de nuevo se suscitaba sobre nuestra admisión en Córcega, de cuio mal temperamento, excasez de víveres, y falta de havitación para alojarnos, nos dieron noticia a los del Navío el General; diciéndose que aún en la Bastia havía desalojado de su Combento a los Capuchinos el Gral. Francés, para alojar en él a su tropa.

Día 12, siguió la falta de viento, y nuestra detención aún en Sto. Stephano. Este día vinieron al Navío el General varios Jesuitas por todo el día de varios de los otros Navíos, y cntre ellos algunos de los que se havían transbordado a la Capitana del Navío Sueco el Blestkolm; por quienes entre otras cosas supimos, el sentimiento con que el Capitán Sueco se havía apartado de los Jesuitas, llorando él, y toda su tripulación, de quien se hacían lenguas. Lo mismo havíamos sabido que sucedió con su Capitán Inglés a los Jesuitas de Málaga, que havían venido hasta Civitavechia en el Navio Inglés llegando a ofrecer que de valde llevaría a los Jesuitas, aumentando a su costa marineros que diessen a la bomba, el tal Capitán Inglés era Cathólico. Oy por la mañana nos asustó a todos los del Navío Sueco el General la caida del P. Prepósito, que venía en él, del lo alto del combél del Navío hasła lo hondo de la bodega, sin haverlo podido impedir, aunque lo procuró el Jesuita Coadjutor, joben del Colegio Inglés, a quien costó su intento el caer con el P. Prepósito, quien se abrió un jente la carne de la frente, 
y a la hora que éste se escrive no a tenido otra resulta, el otro no se hizo lesión alguna; la altura de donde fue la caida es de 6 a 7 varas. Oy supimos que en Córecga havían muerto tres Jesuitas de los que allí havía; ya havía muerto otro en Civitavechia de los que llegaron a ella de Toledo, y era el P. Joseph Velasco, ${ }^{56}$ Provincial que havía sido, y se enterró en el Combento de Dominicos, que allí es la Parroquia principal.

Día 13, amaneció el tiempo en calma, y nosotros aún detenidos. Este día algunos de los Jesuitas que estábamos en el General fuimos en el bote de la Capitana a visitar a los de la Paz, en donde vimos a los sugetos de los Colegios de Cádiz, Baena, Puerto de Sta. María, Carmona, Marchena, San Lucar, Morón, Virera, algunos de los de Granada, y otros varios con quienes nos consolamos mutuamente, por todo el día que passamos allí, como otros de otros navíos en la Capitana, otros en el General.

Día 14, antes de amanecer, disparó la Capitana pieza de leva, y se comenzaron las maniobras para la salida, más ésta se suspendió, haviéndose avistado a las 8 de la mañana 4 Navíos con la proa hacia el puerto. En él finalmente entraron, y eran el navío Español de Guerra San Genaro, al mando del Capitán D. Diego de Argote Cordovés, y otros tres mercantiles, en los quales venía parte de la provincia de Castilla hasta 300 y tantos; 200 en el Navío de Guerra (entre ellos el Provincial P. Osorio, ${ }^{57}$ hijo del Duque de Grajales, el P. Joseph de Barzia, ${ }^{58}$ hermano del Sr. Obispo de Córdova, el P. Isidro López) ${ }^{59}$ y los demás en los otros, uno de los quales era el P. Pedro de Calatayud, ${ }^{60}$ que haviendo estado antes del destierro casi baldado, aora estaba bueno, en medio de las incomodidades de la navegación. Esta la comenzaron el día 24 de mayo en el Ferrol, de donde haviendo salido juntos con el Navío de Guerra San Juan Nepomuceno ${ }^{61}$ al mando del Capitán D. Joseph Valdez y varios otros mercantiles con los demás Jesuitas de la provincia de Castilla hasta el número de 801, por un temporal que les entró aquél mismo día se separaron, sin haver buelto a avistar estos Navíos en lo restante del camino, que han tenido feliz por lo demás. Inmediatamente que dio fondo la Capitana San Genaro, vinieron varios oficiales cordovezes, y un Jesuita de los del Comboy a visitar en el General a varios otros Jesuitas sus hermanos y parientes. Por ellos tubimos noticias varias sobre nras. cosas en España, y sobre su modo de prisión y camino, lo que la Gazeta de Olanda trajo sobre nuestra expulsión, y sus motivos; que el P. Idiaquez ${ }^{62}$ havía venido con los jesuitas de Toledo, y ya estará en Córcega, que de los castellanos, venían hasta los más ancianos de 80 y más años, sin excepción de otra, incapaces por fenéticos, que la expulsión de sus Colegios en muchos havía sido tan ejecutiva que muchos no habían tenido aún 4 horas de término desde la intimidación del Decreto, y eso reducidos desde el mismo instante a una sala, sin dejarles más que la poca ropa que traían cncima, sin otro utensilio, ni un maravedí con que comprarlo en adelanto; que la salida havía sido incommodíssima en los más, haviendo tenido que caminar 80 leguas los que podían haver llegado a puerto más cercano en viage de solas 20 leguas, que muchos, como los de Avila, havían salido en burros con aparejos redondos, en extrivo de soga, y obligados a caminar inmediatamente a la intimación una jornada de 10 leguas; que la salida fue de los puertos de Santander, la Coruña, y el Ferrol, a donde se vinieron a juntar los de los dos puertos primeros; que en medio de lodo, lodos benían y havían benido bien a cxcepción de uno que murió en las inmediaciones al Ferrol, donde se enterró, todos resignados y aún alegres con la disposición del Señor, y con la noticia que le dimos de nra. igual conformidad. Esta tarde los Jesuitas visitados por los de San Genaro, fucron a pagar la visita a aquel navio, y de camino vieron a los Jesuitas de él, y de los otros, entre cllos a cl P. Calatayud, y el P. Nicolás Zubiaur, ${ }^{63}$ su compañero, de quienes trageron muchas expresiones para los jesuitas de su provincia de Andalucía, con muchas otras noticias que oycron sobre varios assumptos que descaban saber, y nos comunicaron. Esta misma tarde fue nro. Comandante Lombardón a verse con el de San Genaro, de quien fue llamado. 
Día 15, a las 2 de la madrugada se levantó una tormenta de agua, aire, relámpagos y truenos, que acercándose a las 4 vino a ponerse sobre nros. Navíos con grande estrépito, que nos hizo a todos dispersar, y asustarnos no poco, por lo frequente de los relámpagos, y lo inmediato y ruidoso de los truenos. Estos por fin comenzaron a cesar a las 5, aunque no cesó el aire ni el agua hasta más entrado el día. Con estar este bien cerrado de nubes a las 10 de la mañana hizo el comandante con un cañonazo otra señal de leva para salir; esto nos causó sentimiento, por el tiempo borrascoso que teníamos por defuera y los aparatos de nubes que registrávamos por todos los orizontes, más de este susto nos sacó el Señor, aunque con otro no pequeño, y fue, que a las 11 virando ya la Capitana para salir del puerto, o por descuido en las maniobras, o por no obedecer la Capitana al timón, haviendo de repente apretado el Sureste no pudo dar el bordo, o torno entero, y cediendo al viento se vino hacia el Navío el General tan derecha y tan cerca, que a pocas varas de distancia de él según traía dirigida a él la proa, temimos los que íbamos en dicho General irnos a pique en un momento hecho pedazos nro. Navío por el ímpetu, y golpe de la proa del otro que venía derecha al costado del nuestro; y duró assí hasta mui corta distancia, en que por fin se ladeó hacia nra. popa, por cuya cspalda passó, dejándonos dando gracias a Dios que nos havía librado de este peligro; si bien no dejó de tener otro la misma Capitana y lue que llevada de viento vino a dar cerca de Orvitelo en parage de tan poca agua, que a poco más que huviera andado huviera encallado; lo que evitó arrojando repentinamente el áncora, y bolviendo a dar fondo, con lo que por oy se suspendió nra. salida, y quedamos libres deste susto. Esta tarde a las 7 llegó el Navío de Guerra Español San Juan Neponuceno, con otros 200 Jesuitas Castellanos, y otro de los tres del comboy, que se scpararon en el Ferrol; llegaron la tarde antes a Civitavechia, de donde aquella mañana salicron para este puerto. Este es el primer viage que hace este Navío Español, de 70.

Día 16 (de San Juan Francisco Regis) estubo el tiempo por la mañana capaz de que se digesen muchas Missas en honor del Santo, hasta las 8 en que la Capitana hizo señal de leva. A las 9 salimos casi a remolco, adelantándose a todos la Nave Sueca el General hasta haver passado la Punta de Monte Argentaro, y ya frente a la Isla de Gigio. Entonces la Capitana haviéndole faltado el viento, disparó un cañonazo al General para señal de bolver al Puerto, a donde retrocedimos, y entramos a las 11 . Al mismo tiempo entró otro Navío del comboy de Castilla, que venía atrazado a los otros. Y últimamente, a la tarde entró el último de dicho comboy que venía con San Juan Nepomuceno a Civitavechia. Esta tarde misma vino a visitar al P. Provincial, y demás Jesuitas que venían en el General, al P. Isla ${ }^{64}$ (con el P. Rector de Santiago de Galicia, y otro Jesuita) a quien celebramos conocer por su fama, y lubimos el gusto de tratar por algunas horas; venía en el Navío San Juan Nepomuzeno, y estubo a peligro de quedar en España por un insulto que le dió al leersele el Decreto de extrañamiento en Pontevedra, donde vivió, y le repitió en Santiago, ya de camino para embarcarse; por rigor del Juez comicionado en Pontevedra apenas pudo sacar y traer su Fee de Baptismo, y títulos de Ordenes. Nos dió muchas noticias, que nos pusieron en desseo de otras muchas más, que no permitió la limitación de tiempo. Entre otras supimos ser cierta la de la carta de un religioso de cierta Religión escrita el verano passado a otro, anunciándole próximo el golpe que amenazaba a la Compañía, para lo que ya le decía estaban tomadas las medidas loaas, y sobre lo que le pedía sus oraciones para tan Santo fin; la cual carta contextó dicho Padre que vino a manos del Sr. Obispo de Guadix que la remitió certificada al papa; a quien no dejará de haver servido para su govierno en las circunstancias. Nos dió también la de haver salido poco antes de nro. destierro carta circular del General Carmelita, ${ }^{65}$ en que dize a sus Religiosos, que el Provavilismo de 200 años a esta parte ha hecho más daño que todas las Heregías juntas. Nos dijo que ya dejaba imprimiendo el Tomo de Noviembre del año christiano, y el de Diziembre, en Valladolid, que el tomo primero de Fr. Gerundio podía aña- 
dir otros sus no inferiores. Fuera de estas y las demás noticias que tubimos por dicho Padre, no ocurrió oy cosa especial.

Día 17, nos mantubimos en el puerto sin otra novedad que avernos dicho nuestro Cirujano, que de Civitavechia le havían assegurado en uno de los Navíos recién llegados, que havía allí muerto el uno de los tres enfermos Jesuitas, que dejamos; y según las señas era el Coadjutor Ropero de San Hermenegildo de Sevilla.

Día 18 (del Corpus), al amanecer se empalezaron los dos Navíos San Genaro, y San J. Nepomuceno, el nuestro no, antes a las 8 , hizo señal de leva, y a las 9 comenzamos a caminar con Sudoeste, después de haver dicho varias Misas, y Comulgado los demás. A las 8 de la tarde, nos hallamos ante el Monte Christo, que passamos aquella noche, como también la Ysla de Elva, donde está Porto Longon perteneciente oy al Rey de Nápoles.

Día 19, después de varios bordos, dados esta noche nos hallamos oy a las 6 de la mañana entre la Punta última de Elva y la Ysla Planosa distantes una legua; la qual apenas se descubre hasta llegar a ella. A las 9 puso la Capitana señal de haver visto la tierra de Córcega, con vandera española. Esta tarde el comandante mandó a la Saetía que se adelantasse a la Bastia, a saber las órdenes que allí havía. Los demás Navíos seguimos a la Capitana acercándonos a la plaza hasta la distancia de una legua, y allí quedamos a la noche a la capa, sin incomodidad, por la calma que hizo.

Día 20, al amanecer llegó de buelta a la Capitana la Seatía con orden, que el comboy nro. de Andalucía se dirigiese a San Fiorenzo, como se comenzó a ejecutar, virando la Capitana hacia Cabo Corso, ${ }^{66}$ para montar la Punta de Córcega, Io que no se pudo en todo aquel día, ni los dos siguientes; por que al tocar la Punta, nos impidió seguir un viento Sudueste tenaz, que comenzó este día a las 11. Mientras caminamos hacia la Punta de Córcega, fuimos observando todo aquel lado de la Ysla, comenzando desde la Bastia, que aparcció una población no pequeña, y bastantemente divertida y amena, en una especie de altura dominante a el mar, a la falda de las montañas que por este lado se ven, pobladas de diferentes lugaritos, ya en los repechos, ya a la lengua de agua, todos vistosos por su situación y por lo ameno y frondoso de aquellas montañas, o faldas, parecidas a las de la costa de Málaga. Oy por la mañana acercándose a nro. Navío Sueco el General la Saetía, tubimos el gusto de saber por los Jesuitas que venían en ella, y havían ido en ella a la Bastia, que traían buenas noticias; en particular nos digeron que en la Bastia estavan los Jesuitas de Aragón, entre los que viene el célebre P. Codorniú ${ }^{67}$, que ya llevaban 28 días de estar anclados, que todos los días alternativamente, saltaban en tierra la mitad de ellos por la mañana y tarde con facultad de passearse, y ir al Colegio que aquí tenemos a decir Missa; que aquella tarde vinieron a bordo de la Sactía a visitar a los Jesuitas Andaluzes, varios P.P. Aragoneses, entre ellos dos hijos del Conde de Fuentes, ${ }^{68}$ que dieron refresco de Agua de Nieve a los P.P. Andaluzes, y que a no haverse hecho a la vela la Saetía aquella tarde para bolverse, huvicra venido visitarlos el P. Provincial de Aragón. Dieronles dichos P.P. las noticias de que los Obispos de España havían pedido al Rey licencia para hablarle, y que se la havía concedido; que el Consejo de Castilla estaba quejoso de no haver sido consultado sobre nro. extrañamiento; que se sabía nos havían levantado el testimonio, de que en una esquela que se encontró en cassa del Marqués de la Mina (que murió el 25 de Enero de este año) se ponía la noticia de una conspiración contra el Rey firmada de Magnates, ayudados de 30 Jesuitas; y que la conspiración, o conventículo fue el 27 del mismo Enero, dos días después de la muerte del Marqués. En fin, que dichos P.P. Aragoneses esperaban estar ciertamente en sus Colegios, como nosotros en los nuestros, para el día de N.S. Padre. No pudieron especificar más cosas porque el aire separó nuestras combersaciones. 
Día 21 (de San Luis Gonzaga) amaneció tan recio el aire, que apenas permitió se digessen con mucha precaución algunas Missas en que comulgaron los que pudieron. Todo el día siguió el viento y cada vez más recio de modo que al medio día estaban muchos mareados por lo aorzado del Navío y sus baibenes. Estos se aumentaron a la tarde, y más a la noche, que con su silencio y el sumbido del viento, junto con los balanzes, fue para casi todos, sino la peor, de las peores que hemos experimentado en nro. viage, siendo el menor trabajo el no haver podido dormir por el susto,y ruido repetido de las maniobras. Bendito Dios, que nos quiso dar este día de nro. S. Luis Gonzaga, cuya Novena havíamos empezado.

Día 22, a las 2 de la madrugada se templó algo el viento pero quedó la resulta de los balanzes, que duraron hasta el medio día, en que bolvió a arreciar y siguió toda la tarde, en la que haviendo avistado varias embarcaciones de quien se recelaba la Capitana hazia las cercanías de Córcega frente a la Bastia, disparó un cañonazo a la más inmediata, que promptamente arrió vandera y se vino a la Capitana, a quien dió razón de todo; y assí descuidada siguió con nosotros la Capitana, comenzando a retirarse de tierra por temor del viento contrario, que iba cada vez apretando, con lo que aquella noche se separaron de la Capitana, y el General y Navío Francés, las otras embarcaciones.

Día 23, desde media noche en adelante se enfureció por instantes mas el viento y el mar de modo, que apenas dejó dormir a nadie, sobresaltando todos y mareados summamente con los balanzes, que fueron desde aquella hora hasta las 12 los mayores que havíamos experimentado; con esto muchos no estubieron para comer junto con haver empezado a nauseas la comida, que desde Civitavechia havía sido de carne de oveja, y ya desde el día antes no havía havido garbanzos para la olla, que assí estaba desabrida. A las 12 del día por fin nos hallamos ya montada la Punta de Córcega, y viramos hazia San Florencio a todo trapo; pero a las 5 de la tarde después de haver tenido tanto viento por quatro días, nos hallamos en calma entre San Florencio y Cabo Corso; y assí huvimos de passar toda la noche cerca de tierra por el lado de Córcega que mira a España, que nos pareció mui árido, inculto, infructuoso, montuoso, y poco avitado.

Día 24, nos comenzó a hazer algún viento del mismo, y comenzamos a acercarnos al puerto, tan despacio, que gastamos todo el día, y al fin fue menester por la tarde remolcar el Navío con la lancha hasta una legua antes de tierra, que se hechó el áncora a las 8 de la noche en el navío el General, haviendo encorado antes la Capitana más cerca de tierra. Esta noche a las 11 entraron en el puerto la Saetía y Barco Longo que havíamos avistado este día desde las 12, y se havían separado de nosotros por el temporal, hacia la Bastia. De los demás a estas horas no sabemos. Esta noche misma luego que dimos fondo, bino en un Bote al Navío el General, el Comisario que aquí havía del otro Comboy de la Provincia de Toledo, ${ }^{69}$ que estaba aquí; por él supimos que los P.P. de dicha Provincia estaban aquí 27 días havía que sus Navíos havían sido lletados por tres meses; que no haviendo sido recibidos en Civitavechia se dirigieron a Córcega, que en la Bastia no fueron recibidos por el General Francés por no haver allí más en que havitar que la Bastia, y tres o quatro Pueblos pertenecientes a Génova, ocupado ya lo demás por Paoli, que venidos a este puerto de San Florencio se hallan aora como nostros con la novedad de que haviendo conseguido unas ventajas Paoli sobre los Genoveses, casi todos estos lugarcillos establecidos a Poniente de esta Ysla pertenecen a Paoli, apoderdo de ellos, a excepción del puerto ocupado por los Franceses; que al principio no permitía Paoli se diessen víveres a los Navíos; después permitió se les surtiesse de pan a peseta la hogaza, y carne de baca a 8 quartos por libra de onzas; que por la Ascensión se apoderó de la Ysla Caprara con 300 hombres, en cuya cclebridad eran las luminarias que observamos aquella noche; que quando vinieron a Córcega se les dijo esperassen por seis días la razón, que aún no ha venido después de 28 ; 
que los Jesuitas de Madrid vinieron sin equipage, que aunque quedó para embiársele después detrás de ellos, al fin no se les embió, diciéndoles que importaba más que ellos su conducción; que aquí saltan en tierra todos los días, como en la Bastia, en donde el Comandante Francés tenía su alojamiento en el Colegio de los Jesuitas, con su muger y familia.

Día 25, a las 5 de la mañana a favor de algún viento, y con ayuda de la Lancha se acercó más el Navío el General al puerto más adentro del de guerra, y allí dimos fondo. Aquella mañana nos vino a visitar de los primeros el P. Francisco Javier Ydiáquez, Provincial que acavava de ser de Castilla, hermano del Duque de Granada en quien havía renunciado los derechos de Primogénito para entrar en la Compañía. Vino acompañado del P. Antonio de Zacagnini, Jesuita de Andalucía, ${ }^{70}$ que era Maestro del Príncipe, el qual salió desterrado como todos, sin dejarle lugar para despedirse del Príncipe, como tampoco el P. Velingen, ${ }^{71}$ que era también Maestro de Mathemáticas del Príncipe mismo, y que igualmente salió extrañado, aunque ambos con sus honores y sueldo de mil pesos. A más de éstos fueron muchos los Jesuitas Toledanos que nos visitaron en este día, y por quien tubinos muchas noticias que en parte sabíamos, y en parte ignorábamos.

Día 26, siguieron las visitas de dichos Jesuitas; entre ellos los más nombrados fucron el P. Provincial Maurín, 72 Predicador que cra del Rey; el P. Antonio Espinosa célebre traductor de la obra del Pueblo de Dios, ${ }^{73}$ ya anciano con muletas, y el P. D. Joaquin Navarro Rector del Colcgio Imperial, ${ }^{74}$ que actualmente estaba imprimiendo la Theología, y por quien tubimos noticia del modo como por un Religioso Francisco supo el Decreto de nuestro extrañamiento el juebes de la semana antes que se ejecutasse, y las diligencias que hizo con su noticia $\mathrm{cl} \mathrm{P}$. Eustachio de Medina, Rector del Noviciado, 75 Maestro que havía sido de Prima en el Colegio Romano después del P. Barba. Oy por la tarde empezaron a parecer varios Navíos, que úliimamente se conocidó y vió que era el Comboy de la Provincia de Castilla, que haviendo salido de Sto. Stephano el día después que el nro., por las calmas havía estado detenido; el primero de todos entró al fin del día el San Genaro; después varios otros.

Día 27, siguieron entrando los Navios del Comboy Castellano, y con ellos los tres del nro. cl lrancés, el olandés, y el sueco la Paz, que entró al medio día, cerrando a todos el San Juan Nepomuceno; en lo que, y en visitas de todos los Jesuitas se passó el día.

Día 28, continuó nuestra cstada en el puerto, y visitas de los Jesuitas de ambas Provincias; entre los quales los más conocidos fueron: el P. Joseph de Barcia, hermano del Sr. Obispo de Córdova, que quedó a comer en el General, combidado por los P.P. de su Andalucia, a quien conservaba cariño, y memoria; el P. Pedro de Calatayud, que haviendo estado enfermo antes de nuestro destierro desde él estaba mejor que antes de enfermar, y se mancjaba mejor.

Día 29 (de San Pedro) siguió lo mismo sin otra novedad.

Día 30, no ocurrió otra cosa que haver comenzado a saltar en ticra aquel día algunos jesuitas de nuestro Comboy por condescendencia de nro. Comandante, a ejemplo de los del Comboy Toledano, y cl de Castilla, que lo permitió inmediatamente a su llegada al Puerto.

Día 1 de Julio siguió lo mismo sin más novedad que haver venido a nro. Navío el General (y lo mismo a los otros) a hacer lista de los víveres que teníamos, dicen que para determinar sobre nra. ida a Génova a hacer víveres. Oy se supo por carta de Roma atrasada que S. Santidad havía mandado curar y asistir a su quenta a los Jesuitas que Ilegaron cnfermos a Civitavechia; ya havían llegado de aquel puerto a éste algo mejorados dos de los tres enlermos Jesuitas andaluces que havían quedado allí, y heran el Sacerdote, y cl Coadjutor que falsamente se nos havía dicho haver muerto, quedando allá sacramentado el Estudiantc, ${ }^{76}$ sin $\mathrm{el}$ 
consuelo de que quedasse allí el sacerdote para su consuelo a la hora de la muerte. También havíamos visto fuera de otras papeletas de noticias las de una copia que corría en Roma, como por respuesta del Papa a la carta del Rey en la que Su Santidad comienza quejándose desconsoladamente de haver experimentado, después de tantos golpes en sus últimos años, éste, que llama el maior, de nro. extrañamiento. Sigue con el texto $T_{u}$ quoque fili $m i, 77$ lamentándose de que el Cathólico Rey sea el que con este golpe Ilebe su triste ancianidad a la sepultura dando su brazo a los enemigos de la Yglesia para la extinción de una Religión tan útil a ella, y que debe su fundación a la España misma en sus fundadores preelegidos por Dios de esta Nación. Se hace cargo con que el Rey mismo que no permitiera se hiciesse la menor vejación al mismo tiempo de sus súbditos sin oirlo antes en juicio, haora este mismo Rey condene con infamia y castigue a un Cuerpo entero de religiosos vassallos suyos, sin avisarlos, sin sitarlos, sin oirlos, sin convencerles. Y concluye pidiéndole por el SS. Nombre de Jesús carácter de los hijos de San Ignacio, por la Puríssima Concepzión tan defendida siempre por los Jesuitas; y últimamente por su afligida ancianidad, que revoque o suspenda el Decreto hasta oir en Justicia a los Jesuitas, dando oidos a los Juezes competentes, a los Pastores de la Yglesia, a los Religiosos, y personas desinterezadas, como espera fiado en su bondad, y rectitud de sus intenciones, y firma el 16 de Abril.

Día 2 (de la Visitación de Nra. Señora) siguieron las visitas de los P.P. de otras Provincias, entre ellos del P. Tirado ${ }^{78}$ de la Provincia de Toledo, que en tiempo del Sr. Rubio Obispo de Jaen hizo missión en aquel Obispado. Supimos venir en el Comboy de Toledo el P. Eximeno, Director del Seminario de Artilleros de Segovia, poco há fundado por el Rey; ${ }^{79}$ el P. Cerdá, Aragonés, Maestro de Mathemáticas del Seminario de Nobles, y el P. Benavente del Colegio Imperial ${ }^{80}$ que havía de ir a serlo de Sevilla que intentó fundar S. Sebastián Caballero. Supimos también que Su Santidad havía escrito tres Brebes a los tres Cardenales Españoles de Toledo, Sevilla, y Patriarcha, para que recurriesen al Rey a favor de los Jesuitas. En lin, que por el P. Barona (Confesor de la Reyna Da. Maria Bárbara, que también viene aquí en el Comboy de Toledo) havían sabido los P.P. de Madrid, algunos días antes, el Decreto de nuestra expulsión, a que permitió Dios que nunca se persuadiessen.

Este día repentinamente se levantó la voz, de que nos admitían en Córcega para colmo de nuestra desgracia y fortuna cada día más adversa. De hecho esta tarde en que cumplimos cabalmente dos meses de nro. embarco los que salimos de Sevilla, se nos dió por fija la noticia de que a las 5 llegó un Correo del Comandante Francés de la Bastia, en que a nros. Comandantes avisaba tener ya Orden de admitir a los Jesuitas en los quatro únicos Pueblos en que ai Tropas Francesas de Guanición, que son la Bastia, San Florencio, Calvi, y Ayaccio, para lo que desocupará estos Pueblos de 2.000 de los 5.000 soldados Franceses que ai actualmente remitiendolos a Francia en los Navíos en que vienen los Jesuitas Españoles, de los que 600 se repartirán entre los tres últimos Pueblos, y los restantes en la Bastia en los quarteles que en estas Plazas dejan desocupados los soldados, que son unas malas casas cayéndose, sin techos, sin abrigo, sin asseo; y tales que los quarteles de España se pueden tener por Palacios respecto de éstos, en que será menester estar tan estrechos e incómodos como los soldados, sino más, por ser más el número de Jesuitas que les succeden que el de los soldados que salen. Esta noticia llenó a todos los Jesuitas de la consternación que se puede pensar, comenzando por la reflexión que hemos hecho en todo el curso de este negocio, y es que todas las novedades adversas las hemos tenido en viernes, y assí creemos y tememos que mañana viernes 3 de Julio se nos notilicará el último extremo de nra. infelicidad de resulta de un Consejo de Guerra que esta noche han tenido los Comandantes de los tres Comboys por día de la Visitación de Nra. Señora, que con estos golpes nos la ha querido hazer oy tan afligida y memorable. 
Oy por la mañana se enterró el P. Mayo ${ }^{82}$ de la Provincia de Toledo en un Combento de San Francisco que está en la falda de las Montañas junto a San Florencio, adonde lo havían embiado a curarse de una Etica; era de 35 años, y esta tarde estubo para ahogarse el Guardiamarina D. N. Angulo Poblaciones al bañarse en el mar a no haverlc socorrido, sacándolo dos padrecitos Andaluces que se arrojaron a él por estar cerca, y saber nadar.

Día 3, continuaron las tristes nuevas de ir a desembarcar las quatro Provincias en Jos pucrtos de Bonifacio, Ayaccio y Calvi, poblaciones tan pequeñas que se pueden compararse con San Juan de Alfarache junto a Sevilla, o Purchil junto a Granada, pues según nos las pintan son muy inferiores a San Florencio, y ésta es tal que a más de los 200 Franceses que hay en ella aquartelados, sólo dizen que caben unas 160 personas; y en estas tres poblaciones tan chicas habrán de hospedarse casi tres mil Jesuitas, con quanto estrechez e incomodidad, ya se deja entender, y no es fácil explicar sino viéndolo; y más no teniendo nosotros más utensilio que el tal qual colchón que traemos (y el de muchos es de munición de soldados) que ya en muchos apenas puede servir; sin más tarima, cortinas, esteras, sillas, mesa, belón, ni otra alguna cosa ni esperanza de tenerla en lo humano; y en una tierra donde no es fácil surtirse ni de ella ni de otra, porque a estos puertos, como que en nada abundan no se aporta embarcación alguna, ni del País, que no las tiene, ni extranjeras; con lo que estamos persuadidos que todo lo que hemos padecido (que es indecible) en el Navío, es nada en comparación de lo que nos espera en estos alojamientos, a que se añade que según la experiencia que tenemos ya, esta gente es mui interesada, y por todo lleban un ojo, y más siendo muchos los que hemos de gastar, y pocos los géneros que ai en el País, adonde ni noticia llega de que ai mundo, ni ai por donde darla al mundo de nosotros, siquiera para que se compadezcan de nosotros, y tengamos ese consuelo, ya que no pueda darnos otro mientras Dios nos tenga en esta infeliz tierra, y entre csta gente rebelde para que en algún modo se cumpla aquel et cum iniquii reputatus est, pues para colmo de todo estos pueblos están en guerra con la República de Génova que sólo posec Ios tres dichos, y el de San Fiorenzo y la Bastia que son los mejores; pero en ellos no podemos desembarcar por cstar ocupados de los franceses soldados, y los tres a que bamos los han desocupado para nosotros dejándolos con esto expuestos a que el General Paoli, cabera de los rebeldes, se apodere de cllos, y entonzes los enemigos de la Compañía nos atribuirán esta acción para indisponernos con la República de Génova, y hacer que los heche de su territorio, sino es que con esta mira se ha hecho ésto. Hágase la voluntad de Dios, que tanto quierc que padezcamos sin haver tenido en tres meses que ban desde el Decreto, sino motivos nuevos cala día para nuevo y mayor servir y penar sin intermisión.

Oy ha corrido la noticia de que el Consejo de los rebeldes de Córcega ha cscrito a Paoli que puede admitimos en su distrito con un carta mui honrrosa a nosotros. A la que Paoli ha respondido honorilicamente que nos admite por dichos motivos de instruir a los Corsos a no temer que nosotros influyamos con nuestra educación, y buen genio en los naturales afin de que la Ysla se sujete otra vez a Génova; lo que todos ellos aborrecen de corazón, tanto que sicmpre handan armados contra los Genoveses para quitar la vida a qualquicra de cllos on encontrándolo, en lo que crían desde chicos a sus hijos. Esta tarde se levantó un Poniente mui recio que alborotó la Bahía, y impidió que los Navíos de nro. Comboy Andaluz se pusiessen a pique para marchar, como havía mandado nuestro Comandante sin decir adonde.

Día 4 (de S. Laureano, Arzobispo de Sevilla), siguió por todo el día cl viento furiosamente llegando a marearnos aun estando parados, teniendo ésto más que ofreceer a Dios a quien ya pedíamos por misericordia el desembarcar, siendo tan penoso, por juzgarlo menor mal que los que padecíamos. No ocurrió otra novedad este día, más que las mismas, que los antezedontes. 
Día 5, desde la madrugada comenzó a amainar el viento, aunque él havía sido tal, que por todo este día siguieron balanzes y mareos, aunque ésto ya no impidió el que pudiessemos tencr algunas visitas de P.P. de otros Navíos, entre ellos del P. Osorio, hijo del Marqués de Grajales, Provincial actual de Castilla, y del P. Ysidro López, como también del P. Ordeñana, ${ }^{83}$ de quien oimos varias noticias sobre el estado de nuestras cosas en su Provincia al tiempo del destierro. Y siguió la misma indecisión en punto de nro. desembarco en Córcega.

Día 6, seguimos como los antezedentes, aunque oi se entraron en los Navíos, bacas para 8 días de camino, que unos decían para Ayaccio, y otros para Génova; pero después se supo que no saldríamos de aquí, ni desembarcaríamos por aora hasta nueva orden de la Corte, de donde sólo la tenían para arribar a Córcega; añadiéndose que el General de las tropas Francesas en esta Ysla tenía orden de su Corte para ebaquar las plazas que ocupaban sus tropas luego que desembarcassen en ella los Jesuitas; al parecer por resentimiento de Francia de que Génova sin su consentimiento lo huviesse dado para el desembarco.

Día 7, algunos Jesuitas del Navío el General saltaron a tierra, y lograron con permiso del Comandante Francés entrar en San Florenzo donde observaron por menor todas sus calles y casas aquella mañana; conque también entraron en la Yglesia, que en su pobríssimo adorno y fábrica no merecía compararse con la más pobre hermita del lugar más infeliz de Andalucia; apenas tendrá 20 varas de largo, y 5 o 6 de ancho. El todo del lugar mui corto; es de lo más desdichado que puede explicarse, ni aún concebirse. Aún no se explica bien lo que es con decin que todo él es un conjunto de chimeneas, que tales son todas sus casas; en las quales podríssimas, ridículas, negrissímas, se puede decir que todo es chimenea porque en cllas no ai otra por donde salga el humo sino la ventana y puerta, con lo que todas ellas de alto avajo están como la chimenea de la casa más desdichada y del más triste cortijo. ${ }^{84}$ El vecindario no puede llegar a 150 vezinos, y con todo es ciudad que ai Obispo, y mejor que la de Calvi y Algayola, que son dos de las tres destinadas para nro. desembarco; y aun con todo no se explica con todo esto el dictamen que se formó de este pueblo por los que lo vieron; por lo que hizieron juicio que aun después de tanto como hemos padecido desde el 3 de Abril todo ello es nada respecto de la infelicidad que aprehendieron sería y podía ser cl vivir en semejante población; y que en vista de esto, el mayor sacrificio que podíamos hacer a Dios, aun entrando el de 3 de Abril, cra ofrecerse y resignarse en la voluntad del Señor para vivir en esta infeliz tierra; que ciertamente les pareció ofrecerse a morir, assí por los dicho como por las noticias que tenemos de lo dañosa que es, especialmente en estos meses, toda la costa de cste lado de la Ysla donde está este pueblo, y los otros tres señalados para el desembarco. Y assí juzgaron que era imposible que el Rey mandasse desembarcarnos en esta Ysla, si se le informaba sinceramente por estos Comisionados de la situación de esta tierra tan dañosa, y más para unos hombres que por su edad, y sus achaques, por su crianza tan dilerente, y en climas tan benignos como los de España, y con otras comodidades religiosas, imposibles aquí, no merccían tal destino; pero bendito Dios que assí lo dispone, y quiere que vamos a vivir aún con más infelicidad y lalta de todo, que el más pobre soldado en casas de alojamiento, que tales serán las que ocuparemos; pues aún con ser tan malas e incómodas, muchas no serán capazes de más que un sujeto, por lo chicas, ridículas, e indignas de compararse con la choza de un cortijo de Andalucia, no ya con la más vil del lugar más infeliz de España.

Día 8 , bolvió a resucitar la especie de nro. desembarco en la ciudad de Calvi, que cstá en esta costa, y es inferior a San Fiorenzo, en donde sabemos que ai más escasez de pan que en San Fiorenzo, en donde una hogaza de pan de trigo mesclado con maiz vale 3 rls., ¿qué scrá en Cálví? que está más distante de la Bastia, de donde aquí nos surtimos en San Fiorenzo aún de hortalizas tales quales, y de todo lo demás. Con esto bolvieron los ánimos a contristarse de nucvo. 
Día 9, a las 4 de la mañana disparó San Genaro (como Comandante principal de los tres que aquí estaban) la pieza de leva, y a las 8 embió un papel nro. Comandante a los Navíos de su Comboi para que ninguno saltasse en tierra de nosotros este día, y que estubiésemos promptos para hacernos mañana a la vela. A la tarde, a las 4, vino un oficial de marina a dar a nro. Capitán varias instrucciones relativas a nro. desembarco. A la noche por una parte nos dijeron que los Jesuitas de Andalucia ibamos a Calvi con los de Castilla, y los de Toledo, y Aragón, a Ayaccio; y por otra, al contrario; quedando en una confusión sobre la verdad de estas noticias, benidas ambas por verídicas.

Día 10, viernes, fue para nosotros de los más tristes, y comparable con el primer viernes de Abril, en que fue la notificación de nro. extrañamiento. Desde mui temprano corrió por segura la noticia de que nuestra Provincia de Andalucia iba a ser desembarcada según unos en Calvi, según otros más ciertamente en Algayola, Pueblo de 30 vecinos junto a un castillo distante una legua de Calvi, expuesto a las incursiones de los moros, y los corsos. Esto se confirmó por carta que el P. Provincial tubo de los P.P. Rectores que venían en la Paz cn que de común acuerdo les suplicaban lo mismo que ya el P. havía determinado después de consultados Ios sugetos principales que venían en el Navío del P., que cra el General; y después de prevenidos los P.P. Provinciales de Toledo, P. Maurín, y de Castilla, P. Osorio, que combinieron en el pensamiento. Este fue hazer, como se hizo, un Memorial en que el P. Provincial, suponiendo la verdad de este desembarco, protestaba a nro. Comandante Lombardón: lo primero, que haviendo sido nro. destierro a Ios Estados Eclesiásticos por Decreto expresso del Rey, no haviéndose cumplido éste, y no sabiendo nosotros el motibo, para no ser responsables a S.M. en ningún tiempo, necessitábamos, y pedíamos se nos mostrasse otro Decreto formal del Rey por donde constasse la rebocación de él, en cuya virtud se nos desembarcaba en Córcega. Lo segundo que también se nos mostrase Decreto, o Licencia de Ia República de Génova, a quien pertenecía este pueblo, para semejante desembarco, que nosotros protestábamos podía ser motivo de indisponernos con la República, en la suposición de saber, como sabíamos, que al punto que nosotros desembarcásemos saldrían del pueblo los soldados Franceses, con to que el pueblo sería inmediatamente tomado por Paoli y nosotros por una parte quedaríamos cxpuestos a tener que hacer juramento de fidelidad a Paoli, en desagrado de la República, su cnemiga, a la qual la compañía no quería disgustar, como agradecida a lo mucho que la debc; por otra parte en peligro, de que después los mal intencionados para indisponernos con España, con el Rey, con Génova, y con todo el mundo, esparciesen que nosotros éramos tan perturbadores que al instante que entramos en estos pueblos los entreganos o se cntregaron a Paoli. Lo último, que se hiciesse cargo como protestábamos, de la infelicidad en que quedábamos en un pueblo tan infeliz, sin casas en que morar, sin utensilio alguno para nro. acomodo más que el triste colchón, ya en muchos casi inservible, con summa excásez de víveres, carestía de ellos, entre una gente incógnita, montaraz, y pobríssima, expuestos a ser robados de lo tal qual que llcbávamos, y en una tierra en donde no teníamos, ni nos quedaba recurso alguno sino perecer sin medios para salir de ella a buscar en otra la limosna. Por todo to qual se suplicaba al Sr. Comandante suspendiesse el desembarco dicho hasta que pudiessemos recurrir al Ministro de S.M. o al Rey, de cuia piedad esperábamos que no podía permitir se nos descmbarcasse en tanta infelicidad, quando en nro. viaje nos havía mandado atender, y cuidar con tanto esmero a razón de 7 rls. por sujeto para cada día. Este Memorial llevó el P. Prepósío en nombre del P. Provincial, y lo hizo saber extrajudicialmente por moderación de nro. Comandante, que se sorprendió de que se intentase tal cosa, y respondió que no podía admitir semejante protesta sin peligro se ser tenido en Madrid por Reo de Lessa Magestad, que no podía mostar el Decreto; que no havía nada cierto sobre nro. desembarco, que debería ser en Algayola; que cra cierto saldrían los Franceses de él, y entraría Paoli, más que liasscmos de 
Paoli que nos trataría bien; que por lo demás no corriese tal Memorial en público, por que él peligraba. Con esto se despidió el P. Prepósito, de cuya relación de todo ésto vinimos a sacar que no podíamos tener aún aquel recurso que se permite a los reos más infelizes, por mayores que sean sus delitos, para pedir a su Juez, y representarle lo que tengan cn su abono, y que assí ya en lo humano nada teníamos que esperar sino un total desamparo de los hombres por todos lados; faltándonos aún el de la compasión de nros. padres, parientes y amigos que esiarían mui agenos de estas funestíssimas circunstancias. No es fácil explicar la consternación que volvió a apoderarse de nuestros ánimos, que no tenían otro consuelo que hazer actos de resignación frequentíssimos, que era el único desahogo a que ya podíamos apelar. En esto se passó todo este triste vienes, memorabilíssimo para nosotros; y no menos triste por más que algo se pretendió aminorar con la noticia que empezó a correr a medio día, de que por una carta del Comandante francés de la Bastia, se sabía que Paoli estava apostado con tropas en los sitios de nro. desembarco para impedirlo, temiéndonos nosotros según el modo rigoroso de proceder que con nosotros se tenía, que con todo esso nros. Comandantes harían el desembatco de modo que quando Paoli acudiesse, si acudía a impedirlo, ya estarían nros. Navíos hechos a la vela, y nosotros expuestos a quedar de modo que tubiessemos que dejar por orden de Paoli la Córcega, y buscar a nra. costa assilo en otra parte de la Ytalia, y assí quedasse la España libre, y descargada de nosotros para adelante, y el Papa con el cargo de haver de procurarnos, al menos por charidad, en qualquiera parte de la Christiandad, la acogida y amparo que a sus Españoles negaba nra. España. Entre estos pensamientos llegaron las 7 de la tarde a las quales San Genaro disparó pieza de leva para su Comboy, y el de Andalucia. Nucstro Navío el General no hizo por entonzes señal alguna de disponerse para el viage.

Día 11, a las 8 de la mañana disparó nra. Comandanta cañón de leva e inmediatamente nro. Navío Sueco el General comenzó a levar ancla. A las 12 avisó el Comandante el modo que havía que observarse en el desembarco, que éste sería en Algayola por los dos Barcos Longos, y Pingue Malagueño, y por los demás en Calvi, 5 millas distantes más allá; con que no nos quedó duda de nro. destino, que es con la Provincia de Castilla; al mismo ticmpo supimos que en las cercanías de Calvi tiene Paoli mil hombres, no sabemos si para impedir nro. desembarco, o para tomar la plaza luego que la degen los Franceses, después de nra. entrada, como se dice. El Señor, de cuya soberana mano solamente confiamos nos diriga, y encamine, como y donde combenga. Oy sábado 11 de Julio, a las 5 de la tarde.

Después a las 11 de la noche, el Comandante dió contra-orden al Pingue y Barco Longo a quienes havia mandado salir en ella para desembarcar en Algayola; y aquella misma noche supimos que Ios Comandantes no havía tenido para nro. desembarco más orden, que algunas cartas del Ministro, en que suponiendo el desembarco se les mandaba ir a tomar tropas en Barcelona para conducirlas a Cádiz, por lo que los dos Comandantes Vera, y Barceló, de las Provincias de Toledo y Aragón no se havían querido determinar al desembarco de los Jesuitas de su división.

Día 12 , no se dió señal de marcha por que a las 8 entró un Poniente mui recio que duró todo el día, y puso a algunas nubes a peligro de varar contra otras, arrastrando las anclas.

Día 13, bolvió el viento aunque no tan recio, y assí tampoco se hizo señal de salir. A la noche de orden del Comandante salieron el Pingue y el Barco Longo para adelantarse a Algayola, y desembarcar allí.

Día 14 (San Buenaventura), tuvimos por fin la desgracia de arribar después de 73 días de navegación penosa al puerto de nro. destino. Para esto a las 2 de la mañana se hizo scñal de leva, y a ias 6 salimos las dos Provincias de Castilla y Andalucia; al salir avistamos al Comboy de Aragón que havía estado detenido por falta de viento, y seguía nuestro rumbo 
hacia Ayaccio que era el que le tocaba; a las 5 de la tarde arribamos a Algayola pero seguimos hasta estar entre ella y Calvi, donde dimos fondo; y a Ias 6 en que esto sc escrive, quedamos esperando nro. desembarco que no sabemos a esta hora en qual de estos dos pueblos será; nos inclinamos a que los más iremos a Algayola, y algunos a Calvi, los que no quepan en aquel lugar por pequeño, que es lo que más ha corrido. Distan entre sí 2 leguas.

Bahía de Algayola, entre ella y Calvi, 14 de Julio, a las 7 de la tarde, ya dado fondo en ella sabemos que toda la provincia de Andalucia esta noche desembarcamos, y nos alojamos en Algayola para vivir en ella. Dios nos asista en esta infeliz tierra.

\section{DIARIO BREVE DE LA NAVEGACION A ITALIA}

Día 2.- Sábado salimos del Puerto de Sta. María para tomar el Navío que cstaba en la Bahía, en cuya noche quedamos embarcados todos los de Sevilla, y los Colegios de Jaen, Antequera, Ubeda, y Trigueros, que son 154 sugetos; los demás que estaban en dho. Puerto y en Xérez, quedaron también abordo aquella noche o tarde en otros dos Navíos todos Suecos, comboyados del Navío de Guerra llamado la Princesa.

Día 3.- Domingo día de la Cruz nos dimos a la vela con buen viento.

Día 4.- Lunes dimos vista a Africa.

Día 5.- Martes llegamos a el Estrecho de Gibraltar.

Día 6.- Miércoles bolvimos atrás, por viento contrario.

Día 7.- Jucves passamos el Estrecho con trabajo.

Día 8.- Viernes anclamos a vista de Málaga para esperar al resto de la Provincia de Andalucía que nos esperaban para unirse con nosotros en cinco embarcaciones menores que las nuestras, en que iban más acomodados por el número, pero con más riesgo de los vientos.

Día 9.- Sábado salimos todos juntos de Málaga, es a saber: nueve cmbarcaciones, y un Navío Veneciano que se agregó para libertarse de Moros.

Día 10.- Domingo, calma a vista de Sierra Nevada.

Día 11.- Lunes, calma.

Día 12.- Martes, calma.

Día 13.- Miércoles, calma.

Día 14.- Jueves viento, llegamos a Cabo de Gata.

Día 15.- Viernes, calma.

Día 16.- Sábado, calma.

Día 17.- Domingo viento, costa de Murcia y Cartagena.

Día 18.- Lunes viento, Cabo de Palos.

Día 19.- Martes, viento favorable para Alicante.

Día 20.- Miércoles, fronteras de Alicante.

Día 21.- Jueves, frente de Mallorca.

Día 22.- Viernes, viento para Cerdeña.

Día 23.- Sábado, calma.

Día 24.- Domingo calma, y a la noche viento.

Día 25.- Lunes, abistamos a Cerdeña.

Día 26.- Martes la passamos toda con viento fuerte. 
Día 27.- Miércoles calma, y a la tarde viento fuerte.

Día 28.- Jueves día de la Assención no huvo Missa, por viento fortíssimo, y miedo de tormenta.

Día 29.- Viernes, prosiguió el viento con el mismo susto, y dimos vista a Italia.

Día 30.- Sábado, día de Sn. Fernando Rey de España, estando a vista del Puerto de Civita Vechia, y entró calma a las 4 de la tarde, y nos detuvimos hasta las 10 de la noche y entramos felizmente en dho. Puerto.

Día 31.- Domingo, oímos Missa y después nos dieron la noticia de que cl Papa no nos admitía como havía sucedido a los Jesuitas de Aragón y Toledo, que havían ya marchado a Córcega.

\section{JUNIO}

Día 1.- Lunes vinieron cartas de Roma al P. Provincial encomendando ora, y al Comandante para bolverse; de que resultó prevenir víveres para un mes.

Día 2.- Martes, se pusieron tres enfermos a $S^{\text {n }}$. Juan de Dios: un Sacerdote, un Estudiante, y un Coadjutor, y se quedaron allá bien assístidos del Cónsul de España.

Día 3.- Miércoles, se despidió el Navío Inglés por hacer mucha agua, y se transbordaron 33 Jesuítas que traía a las demás embarcaciones, a éste bino el Po. Provincial.

Día 4.- Jueves, a las 10 del día nos dimos a la vela para Orbitelo, donde nos esperaba la Capitana para caminar todos a Córcega.

Día 5.- Viernes, caminamos, después calma, viento contrario.

Día 6.- Sábado, viento contrario.

Día 7.- Domingo, viento contrario.

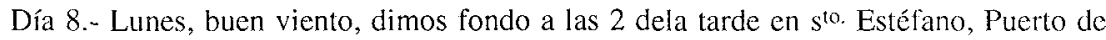
Orbitelo, donde hallamos la Capitana y las demás embarcaciones.

Día 9.- Martes, se despidió uno de los Navos. Suecos llamado el Blasón, por no entrar en el ajuste, y entraron en la Capitana los Jesuitas, que pasaron 150; este día se enterró en dho. Puerto un soldado que murió en la Capitana.

Día 10.- Miércoles, diversos pareceres del término de nuestra navegación: junta de Pilotos en la Capitana para determinar el rumbo que se havía de seguir, y la hora de salir de Orbitelo.

Día 11.- Jueves, dudas de si íbamos a Córcega o a España.

Día 12.- Viernes, prosiguieron las dudas de si íbamos, o sobre si havíamos de csperar aquí o en Córcega Pliegos de España, y consentimiento de Génova y Francia.

Día 13.- Sábado, dió la Capitana señal de salir, y entró viento contrario.

Día 14.- Domingo a medio día, dió fondo en Orbitelo el Navío Sn. Genaro con vasos vizcaynos en que venían los más Jesuitas de la Provincia de Castilla, entre ellos el P. Calatayud.

Día 15.- Lunes, lebamos anclas para salir y bolbimos a dar fondo por tener viento contrario: acabó de entrar la Provincia de Castilla en otras 4 embarcaciones, una de Guerra, su nombre $S^{n}$. Juan Nepomuceno.

Día 16.- Martes, bolvimos a salir, y a las dos horas nos bolvimos a Orbitelo por viento contrario. Vino el P. Isla a ver al P. Provincial.

Día 17.- Miércoles, no podimos salir por viento fuerte.

Día 18.- Jueves, día del Corpus, después de Missas y Comuniones, salimos de Orbitelo para la Bastida, Puerto de Córcega, quedándose allí los 8 Navíos con los Jesuítas de Castilla. 
Día 19.- Viernes, después de una noche mala por viento fuerte y no favorable hasta la 1 dimos vista a la Bastia, adonde embió el Comandante una Saetía para saber lo que havíamos de hacer: estuvimos en calma.

Día 20.- Sábado, bino la Saetía con noticias favorables de nuestra buelta a España. Estava allí la Provincia de Aragón en 17 Saetías, salían a tierra de día, y bolvían a la noche a bordo; decían Missa en el Colegio de la Bastia, y esperaban órdenes de España para lo que havían de hacer. Nosotros partimos para otro Puerto de la misma Córcega llamado $\mathrm{S}^{\mathrm{n}}$. Florencio; caminamos poco por el viento contrario y algo fuerte.

Día 21.- Domingo, Sn. Luis Gonzaga, después de Missas y Comuniones apretó el mismo viento, especialmente de noche, aunq ${ }^{\mathrm{e}}$. sin riesgo mayor.

Día 22.- Lunes, aún fue más recio el mismo viento, y prosiguió el susto especialmente de madrugada.

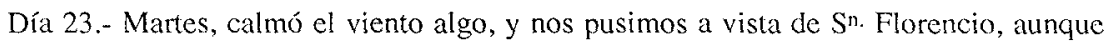
sin poder entrar.

Día 24.- Miércoles, día de $S^{n}$. Juan, calma y viento mui corto hasta las 8 que dimos fondo a la boca de la Bahía.

Día 25.- Jueves, levamos el ancla y entramos en el Puerto de San Florencio, donde encontramos la Provincia de Toledo en 12 embarcaciones. Vinieron el P. Idiaquez y el Hermano y el P. Zacagnini, y otros P.P. a visitar al provincial: vino también el Comandante de la Fragata de Sta. Rosalía y el Jabequín.

Día 26.- Viernes, Corazón de Jesús, después de muchas Missas y Comuniones, prosiguieron las visitas de Andalucía y Toledo.

Día 27.- Sábado, empezó a entrar la Provincia de Castilla, que dajamos en Orbitelo; murió un P. en el camino.

Día 28.- Domingo, acabó de entrar dha. Provar, y nos juntamos en S. Florencio, Toledo, Castilla y Andalucía, y la de Aragón en la Bastia, ambos Puertos de Córcega. Este día llegaron el P. Crus y el Hermano Pérez, y quedó el Hermano Valcárcel ya tísico en $\mathbf{S}^{\mathbf{n}}$. Juan de Dios de Civita Vechia, que son los tres enfermos que se quedaron.

Día 29.- Lunes, día de $\mathrm{S}^{n}$. Pedro prosiguieron las visitas de las tres Provincias; vimos al P. Calatayud y su compañero.

Día 30.- Martes, empezamos a salir a tierra varios sugetos.

\section{JULIO}

Día 1.- Miércoles, Fr. Florencio, prosiguieron en salir a tierra.

Día 2.- Jueves, salí a tierra con otros P.P. y Hermanos.

Día 3.- Viernes, varios dictámenes de nuestro paradero.

Día 4.- Sábado, viento contrario y demasiado.

Día 5.- Domingo, prosigue el mismo viento con más fuerza, y se doblaron anclas por el riesgo.

Día 6.- Lunes, murió otro P. de Castilla, y se enterró en un Combento Franciscano cerca de $S^{\text {n. }}$ Florencio.

Día 7.- Martes, dificultades del desembarco en Córcega por la tropa Francesa que ocupaba los quatro pueblos asignados.

Día 8.- Miércoles, otras dificultades respecto a Paoli que esperaba el retiro de los Franceses para tomar dhos. Pueblos. 
Día 9.- Jueves, orden del desembarco en Calbi, y en Ajaccio, donde havíamos de ser conducidos en Lanchas.

Día 10.- Viernes, dictámenes encontrados de nro. desembarco en Calvi, señal para salir los de Castilla.

Día 11.- Sábado, señal para salir los de Andalucia para Calvi y Ajaccio y Agazola, y órdenes que dió el Comandante para nro. desembarco en Lanchas.

Día 12.- Domingo, viento fuerte y contrario que impidió nuestra salida de $S^{n}$. Florencio, y obligó a asegurar los Navíos con más anclas.

Día 13.- Lunes, calma y después viento contrario.

Día 14.- Martes de madrugada salimos de $S^{n}$. Florencio las dos Provincias de Castilla y Andalucía, quedándose allí la de Toledo; en el camino vimos de lejos a la de Aragón; a la tarde llegamos a Calvi, lugar corto de la Córcega, sugeto a la Génova, donde desembarcamos los de Andalucía.

\title{
VIAGE DE LOS JESUITAS ANDALUCES, Y DESCRIPCION DE AYACCIO
}

\author{
P. Marcos CANO.
}

El día 6 de Octubre se embarcaron en Cartagena; el día 9 a la madrugada salieron del Puerto; el día 10 tuvieron tormenta, y arrivaron al fin de la tarde a Alicante, mareados casi todos; pues sólo permanecieron firmes Cano, y Ossorio. El 13 se hizieron otra vez a la vela; el 15 y 16 tormenta grande, un mar de aguas en que navegar, otro mar de aguas que caía del cielo; otro que suviendo por los costados de la Urca las olas se entraban por los escotillones hasta las camas de los sugetos; rayos y truenos frequentes y furiosos; los balanzes de la Urca tan fuertes que los baules se rodaban de su sitio; los sugetos necesitaban assirse a sus catres para no rodar al suelo; los bómitos continuos; cómo hacía prácticos los sugetos en el camino del Mar, aunque no eran pequeños los aprehendían mayores. Huvo llantos, rogativas, confessiones, y en fín, tal confusión que causaba lástima. El P. Godoy ${ }^{85}$ hizo un bómito el día de $S^{\text {ta. }}$ Theresa, no bomitó más, ni se mareó en toda la navegación. Calmó la tempestad, sosegose cl Mar, siguió la navegación, y el día 19 se entró en el Golfo de León, en donde tubieron siete días de calma muerta, con admiración de todos los Prácticos de aquellos Mares, que jamás la havían esperimentado semejante en este Golfo. Los días últimos de Octubre, 1 y 2 de Novre, mucho Mar, muchos balanzes, mucho viento por la mayor parte contrario. El de 2 con mucha fuerza de vela, y con bastante peligro, lograron entrar al principio de la noche en la Bahía de Ayaccio; entre 8 y 9 de la noche ancoraron, y desembarcaron el día 5.

\section{DESCRIPCIÓN DE LA CIUDAD}

Tendrá poco más de 700 vezinos; está cerrada de murallas fuertes, con un Burgo fuera de ellas. Está situada al pie de un collado con bastante amenidad; mira al medio día, y desde el Mar presenta una vista agradable. En una punta que sale al mar tiene una Ciudadela mui fuerte rodeada de un foso de agua del mismo mar. Los edificios todos altos con 3 o 4 viviendas, la rábrica nada primorosa, muchas bentanas y ninguna reja, parece ser el hierro género aquí prohivido; casi todas las casas son tiendas y parece preciso se vendan unos a otros los tenderos para que haya quien compre. Los mercaderes a los sastres, éstos a los zapateros, y éstos a los carpinteros, y assí a los demás. Tiene una Cathedral de fábrica moderada y de poca exten- 
sión, su Obispo por las Guerras de Paoli se ha puesto en seguridad en Génova. Los Canónigos tendrán hasta cien pesos de renta al año, de modo, que los Jesuitas que allí han Ilegado pueden ser otros tantos Canónigos, y Racioneros los Coadjutores.

Ay Combento de $\mathrm{S}$. Francisco, de Capuchinos, y Colegio de la Compañía, todos de fábrica reducida, y en corta comunidad; una Iglesia con sus sacerdotes para los griegos que componen parte de su vezindario.

En éste los hombres mantienen aún las propiedades que en ellos notó Séneca, que también tubo la desgracia de ser desterrado a esta Isla Prima lex ulcisci, secunda vivere raptu, tercia mentiri, cuarta non colere divos. Son bengativos, y de esto hazen pública profesión. El que ha recibido alguna injuria no se quita la barba hasta haverla vengado. El hurto es arte liberal que todos aprenden, conjugan a rapio rapis hasta por el infinitivo. Es consiguiente el engaño, de que pocos se libran, principalmente los forasteros; ya se infieren quales serán sus costumbres, son ociosos, sólo se ocupan en cazar, y el demás trabajo lo dejan a las mugeres. ${ }^{86} \mathrm{El}$ común de éstas no es fácil pintarlas ni darlas a conocer, sólo tendrá la fortuna de conocerlas el que tuviere la desgracia de condenarse; en viendo los Diablos en el infierno las verán tan retratadas al vivo, que les parecerán ellas mismas; son feísimas, porquísimas, asquerosísimas, furiosísimas, y a estos superlativos admiten todos los posibles.

Al desembarcarse tos Jesuitas havía en el muelle una multitud innumerable de ellas descalzas de pie y pierna, y retratos perfectos de la indecencia, se arrojaron furiosas a las barcas a apoderare de los muebles para conducirlos, se dieron sus puñadas unas a otras para llegar primero; qual carga con una cama, qual con un baúl con tanto desembarazo y pujanza como el montañés más forzudo ${ }^{87}$; pareciáles a los Jesuitas que era despojo, pero al pagarlas el porte que la compasión ellas gritaban con un desentono furioso; ellos no las entendían, y fuc la mayor parte el trabajo de aquel día el pagarlas a su gusto, de aquí se puede venir en conocimiento de lo demás: eo miseriarum devenerunt. Las de segunda clase (que son pocas por componerse la mayor parte del vecindario), quando salen a la calle traen dos pares de enaguas azules, las unas covijadas sobre la cabeza sirben de manto, y la de debajo de saya; assí andan por las calles, y assí asisten en la Iglesia. Las que no han podido juntar las dos enaguas azules usan por saya otras de otro color, y a vezes las blancas. Las de primera clase son poquíssimas, salen a la calle en cuerpo gentil. En juntando un andriel o bata de indianilla se juzgan con dro. de Señorías. En este estado salen de sus casas solas campando por su cuenta, asisten en las Iglesias y se presentan en todas las partes del Pueblo para ser vistas. ${ }^{88}$

Las mugeres de los Griegos bisten de diverso trage, todas de azul; en el ruedo de las enaguas traen dos listas encarnadas de tres dedos de ancho, entre ellas una randa o encaje blanco, una chupa de paño azul hasta las rodillas, chinelas encarnadas, medias de pelo natural, y en la cabeza un casquete de paño encarnado en forma de redecilla; una toalla blanca y largas al cuello, por delante los dos remates tirados a la espalda, y para tocarse dcjan la una punta sobre la espalda hasta más abajo de la cintura tirada con un aire que encanta, y la otra punta la ponen sobre la cabeza para cubrirse. Este es el trage rigoroso de gala que usan, que junto con ser feas, y sin garbo, pueden ser presente para el Diablo. Pues digánme sus Mercedes: traen sotana negra, una chupa larguísima azul sobre ella, barba larga hasta la cintura, pelo tendido hasta media espalda y sombrero de tres picos. Es visión que hiere la fantasía.

El País es mísero, de dinero poquíssimo, los frutos no muchos, pero buenos, y de buen gusto. El fruto dominante es la castaña; ésta es el principal y aún así casi único alimento de todos, y en lo interior de la Isla se haze de ella el pan; ${ }^{89}$ son pequeñas, pero de buen gusto. La baca abudante, el carnero no tanto, pero una y otra carne de buena calidad, y no cara.

Hasta aquí es lo que puedo informar. 


\section{NOTAS}

1.- Recientemente Francisco Borja Medina, S.I., ha utilizado información de estos diarios para su minucioso estudio: "Ocaso de una Provincia de fundación ignaciana: la Provincia de Andalucía en el exilio (1767-1773)”, en Archivo Teológico Granadino 54 (1991), pp. 590. Cfr. Enrique GIMÉNEZ L_PEZ: "El Ejército y la Marina en la expulsión de los Jesuitas de España", en Hispania Sacra XLV,92 (1993), pp. 577-630.

2.- Estos documentos se encuentran en el Archivo Municipal de Sevilla, Sección XI (Papeles del Conde del Aguila), Tomo XII, números 41, 42, 43 y 44 respectivamente.

3.- P. Manuel LUENGO: Diario de la expulsión de los Jesuitas de España (1767-1814) Manuscrito convervado en el Archivo de Loyola.

4.- Constancio EGUÍA RUIZ: “Andanzas de un diario inédito", en Razón y Fe 40 (1914), 323338. Cir. del mismo autor: "Los santos Ignacio y Javier y los jesuitas deportados a Italia por Carlos III (extractos del cronista contemporáneo P. Manuel Luengo) en Miscelanea Comillas, XXV (1956), pp. 267-325; de Miguel CASCÓN: "Manuel Luengo, 1735-1816, su diario y prólogos inéditos fuente de información para el reinado de Carlos III", en Laas Ciencias 14 (1949), pp. 519-543. Ultimamente este diarío ha sido utilizado por Enrique GIMÉNEZ LÓPEZ y Mario MARTíNEZ GOMIS: "La llegada de los jesuitas expulsos a Italia según los diarios de los Padres Luengo y Peramás", en III encuentro "Relaciones culturales España-Italia" Alicante 1994 (en prensa)

5.- Francisco de ISLA: Memorial en nombre de las cuatro Provincias de España de la Compañía de Jesús desterradas del Reino a S.M. el Rey Don Caros III Madrid 1882.

6.- Guillermo FURLONG: José Manuel Peranás y su Diario del destierro (1768) Buenos Aires 1952.

7.- Nicholas CUSHNER: Philippine jesuits in exile. The joumals of Francisco Puig S.J. 17681770 Institutum Historicum S.I. (Bibliotheca Instituti Historici S.I., vol. XXIV). Roma 1964.

8.- Ibiden.

9.- Constancio EGUÍA RUIZ: "Andanzas de un Diario...”, p. 329.

10.- Francisco de ISLA: Op. cit.

11.- A.G.S. Estado Leg. 5.650 Luis Gnecco a Grimaldi 20 de diciembre de 1767.

12.- Guillermo FURLONG: Op. cit. p. 200.

13.- Nicholas P. CUSHNER: Op. cit. pp. 54-144.

14.- Nicholas P. CUSHNER. Op. cit. pp. 42-43.

15.- En el caso del P. Alonso Pérez, Francisco Borja Medina, en su $O_{p}$. Cit., p. 92 , alude a una obra suya que quedó manuscrita bajo el título Comentarios para la historia del destierro, navegación y establecimiento en Italia de los jesuitas andaluces, y memoria para los comentarios del destierro nuestro.

16.- Jesus PRADELLS NADAL y Mario MARTÍNEZ GOMIS: "Viajeros españoles en la Roma de la primera mitad del siglo XVIII", en Quaderni di filologia e lingue romanze, Terza serie, 7 (1992), pp.61-83.

17.- P. Alonso PÉREZ: Continuación del diario del viaje de los jesuitas de Andalucía desde Civitavecchia a 31 de mayo de 1767

18.- Ibdem. 
19.- Ibidem.

20.- Ibidem.

21.- Ibidem. Es probable que estas noticias apuntadas por el P. Alonso Pérez trascendiesen a otros miembros de la Compañía, así como su registro en un diario. A cllas pudo muy bien deberse un incidente citado por Francisco Borja MEDINA en $O p$. cit. pp. 71 -72. Nos referimos al protagonizado por el jesuita José Salvador Vargas Machuca, dimitido en Rímini el 7 de noviembre de 1770 y ordenado más tarde sacerdote. Este, desde Macerata, escribió al conde de Aranda solicitando el 12 de abril de 1772 permiso para publicar una refutación de los diarios del P. Alonso Pérez y del P. Peramás por considerarlos injuriosos al rey y a sus ministros. Resulta difícil, una vez leidos estos textos, encontrar tales motivos.

22.- Guillermo FURLONG: José Manuel Peranás y su Diario del destierro (1768), p. 205.

23.- Adriano Prosperi ha liamado la atención sobre la especialización de la Compañía de Jesús en recoger, elaborar y difundir información, en Adriano PROSPERI: "El misionero", en Rosario VILLARI y otros: El hombre barroco Madrid 1992, pp. 201-239.

24.- Miguel BATLLORI: La cultura hispano-italiana de los jesuitas expulsos. Madrid, 1966.

25.- F. Borja MEDINA: Op. cit.

26. Marcos CANO: Op. cit.

27.- F. Borja MEDINA: Op. cit.

28.- Ibidem, pp. $71-72$ y p. 79 .

29.- A.G.S. Marina leg 724 Relación de los Regulares de la Compañia que salieron de este Puerto el dia de la fecha para la Isla de Córcega Cartagena, 9 de octubre de 1767.

30.- A.H.N. Clero. Jesuitas, leg. 777

31.- José M. MARCH: El restaurador de la Compañia de Jesús, Beato José Pignatelli y su tiempo Barcelona 1935, Vol. I, pp. 200-202.

32.- Los permoneros de estas negociaciones han sido recientemente estudiados por J.A. FERRER BENIMELI: La expulsión y la extinción de los jesuitas segín la correspondencia diplomática francesa (1766-1770) Tomo I, Universidad Católica de Tachira. San Cristóbal 1993, pp. 657 y ss.

33.- A.G.S. Estado Leg. 5.044 Azpuru a Grimaldi Roma, 21 de mayo de 1767

34.- Enrique GIMÉNEZ LÓPEZ y Mario MARTÍNEZ GOMIS: “Un aspecto logístico de la expulsión de los jesuitas españoles: la Jabor de los comisarios Gerónimo y Luis Gnecco (1767-1768)", comunicación presentada a la III Reunión de la Asociación Española de Historia Moderna, celebrada en Las Palmas de Gran Canaria en mayo de 1994 (en prensa).

35.- E. GIMÉNEZ LÓPEZ: "El Ejército y la Marina...", pp. 616-617.

36.- Ibidem.

37.- A.G.S. Estado Leg. 5.044 Grimaldi a Azpuru Aranjuez, 2 de junio de 1767, y Fuentes a Grimaldi París, 19 de junio de 1767.

38.- Ch. AMBROSI: "Les deux annexions de la Corse (1768 et 1789)", en Annales Historiques de la Revolution Francaise 43, 1 (1971), p. 722.

39.- Ibidem.

40.- Enrique GIMÉNEZ y Mario MARTÍNEZ: "Las secularizaciones de jesuitas entre la expulsión de España y la extinción de la Compañáa (1767-1773)”, en la llI Reunión de la 
Asociación Española de Historia Moderna celebrada en mayo de 1994 en Las Palmas de Gran Canaria (en prensa).

41.- A.G.S. Estado Leg. 5.044 Grimaldi a Luis Gnecco Aranjuez, 3 de junio de 1767, y Leg. 5.057 Instrucción al Comisario de Guerra de Marina D. Luis Gnecco, Aranjuez 3 de junio de 1767.

42.- A.G.S. Estado Leg. 5.057 Gerónimo Gnecco a Grinaldi, Calvi, 20 de julio de 1767.

43.- A.G.S. Gracia y Justicia Leg. 667 Consejo Extraordinario e Instrucción Madrid, 6 de julio de 1767.

44.- Se trataba de la Casa Profesa, y los Colegios de San Hermenegildo, Noviciado de San Luis, Colegio de las Becas, y Colegios de los Ingleses e Irlandeses.

45.- Referencia a los navíos suecos General Vankoulbaes y Blas Kolmen.

46.- Juan Manuel Lombardón era uno de los cuatro comandantes de los buques de guerra que debían escoltar hasta Italia a cada uno de los convoyes. Mientras que Lombardón se responsabilizaba de la expedición que partió de Cádiz y Málaga, Francisco de Vera estaba al mando de la flota que se formó en Cartagena con los padres de la Provincia de Toledo, Antonio Barceló escoltaba a los mercantes fletados en Salou y Mallorca, y Diego de Argote, lo hizo al mando de los buques que partieron de el Ferrol.

47.- Francisco Huidobro y Sarabia. De acuerdo con la orden de 3 de abril, que servía de pauta a las actuaciones de los Intendentes de Marina, se preveía el embarque en cada expedición de un comisario, seleccionado entre los oficiales de primera de la Contaduría de Marina, con una cierta cantidad de dinero en metálico con la que poder afrontar cualquier contingencia que surgiera durante la navegación. El Intendente gaditado Gerbaut designó a Francisco Huidobro y Sarabia para la expedición comandada por Francisco Lombardón.

48.- La procedencia de los padres embarcados en Málaga correspondía a Colegios y residencias del territorio del antiguo reino de Granada: Colegio de San Pablo y Santiago de Granada; Colegios de Guadix y Málaga; Residencia de Loja, y Colegio de Motril.

49.- La embarcaciones españolas eran el Pinque "La limpia y pura Concepción", y el Barco Longo "San Antonio de Padua". Los restantes navíos eran el inglés "El Pitt", el holandés "Hoon" y el Crancés "La Isabel".

50.- Este navío de guerra fue el primero que se eligió en Cartagena para cscoltar el convoy que debía partir de aqué puerto. Se pretendía que lo hiciera con las dos terceras partes de su tripulación, y dar cabida así a cuantos jesuitas cupiesen, pero la tardanza de su regreso desde Cádiz, obligó a desestimar su concurso, remitiéndolo a Cataluña para transporte de marinería, a cuyo regreso se cruzó con la expedición que conducía a los jesuitas andaluces.

51.- Vid. nota 47.

52.- La dieta diaria de cada jesuita se reguló detalladamente, y conocemos que el desayuno estaba formado por chocolate, bizcocho o tostada de pan; el almuerzo lo constituia de manera alternativa un plato de sopa, arroz o sémola, acompañada de garbanzos, seguido de carnero, bien asado o guisado. Para los días de vigilia se suministraba garbanzos, habichuelas o fideos, seguido de huevos en tortilla, y bacalao o atún cocido, para la cena se sirvicron ensaladas mientras hubo verdura, y un guisado de carnero o bacalao y atún en los dias de precepto. Una relación pormenorizada de la alimentación de los expulsos a bordo, en A.G.S. Marina Leg. 724 Método que ha de observarse en la suministración de la subsistencia diaria en la navegación desde el puerto de Salou a Civitavecchia a los religiosos de la Compañía de Jesús. 
53.- La expedición procedente de Salou, al mando de Antonio Barceló, con los jesuitas de la provincia de Aragón, fue la primera en llegar a Civitavecchia en la tarde del 13 de mayo. El 20 del mismo mes llegaban a dicho puerto los jesuitas de la Provincia de Toledo, bajo el mando del comandante Francisco de Vera.

54.- El Teniente de Navío Antonio Ocarol recibió órdenes de su comandante Manuel Lombardón para desembarcar en Civitavecchia y pasar a Roma para recibir órdenes del cmbajador español Tomás Azpuru, quien le indicó que se debía navegar hasta Córcega, y que se negociara "con el halago o la fuerza" con los capitanes de las embarcaciones fletadas.

55.- En las negociaciones que el comandante Lombardón efectuó con los capitanes de los mercantes fletados, el del navio sueco exigió 6.000 pesos, cantidad considerada excesiva y que obligó a trasbordar a los 150 jesuitas que transportaba al buque de guerra y distribuirlos en cl entrepuente del "Princesa".

56.- José Velasco cra un sacerdote del Colegio Imperial, y que anterioridad había sido Provincial de la de Toledo. Había sido embarcado en Cartagena el 28 de abril de 1767 en Cartagena en la Urca holandesa "Teodoro", y su óbito se había producido "de repente", en la rada de Civitavechia el 22 de mayo. Su cadáver fue desembarcado y enterrado en la parroquia de Santa Maria de la misma ciudad.

57.- EI P. Isidro Osorio cra Provincial de Castilla desde enero de 1767. Natural de Grajal del Campo, donde había nacido el 15 de julio de 1713, era hijo del duque de Grajales. Jesuita desde el 15 de octubre de 1727, fue embarcado en el Ferrol el 25 de mayo de 1767 en el navío "San Genaro".

58. - José de Barcia era sacerdote operario en el Colegio de Villafranca, en la Provincia de Castilla. Natural de Zamora, donde había nacido el 24 de febrero de 1705, ingresó en la Compañá el 29 de marzo de 1723. Profeso de cuarto voto, fue cmbarcado el 25 de mayo de 1767 en el Ferrol en el Navio "San Genaro".

59.- El P. Isidro López era sacerdote del Colegio de Monforte, Provincia de Castilla. Fue Procurador General en Madrid y desterrado tras los sucesos de 1766. Constancio Eguia Ruiz lo hizo protagonista de su libro Los jesuitas y el motín de Esquilache Madrid 1947.

60.- Uno de los más conocidos misioneros y predicadores de la Compañía. Natural de Tafalla, donde había nacido el 1 de agosto de 1689 , pertenecía al Colegio de San Ignacio de Valladolid, provincia de Castilla. Fue embarcado en el Ferrol el 25 de mayo de 1767 a bordo del paquebotc "San José". Existe una biografía debida a Cecilio GOMEZ RODELES: Vida del célebre misionero P. Pedro de Calatayud de la Compaña de Jesús (16891773) Madrid 1882.

61.- El "San Juan Nepomuceno" era un navío construido en Guarnizo. Partió de El Ferrol con una tripulación de 249 hombres y 147 soldados, más 202 jesuitas. El "San Genaro" lo hizo con 289 hombres de tripulación, 131 de guarnición y 200 padres. Vid. A.G.S. Marina Leg. 724 Estado en que sale del puerto del Ferrol el Navio de S.M. nombrado San Juan Nepomuceno y Ibidem Estado en que sale del puerto del Ferrol el Navío de S.M. nombrado San Genaro.

62.- El P. Idiaquez cra sacerdote del Colegio Real de Salamanca. Había desempeñado el cargo de Provincial de Castilla hasta enero de 1767. Natural de Pamplona, había nacido el 26 de febrero de 1711, ingresando en la Compañía el 19 de lebrero de 1732. Se encontraba cn Madrid cuando el decreto de expulsión, por lo que fue embarcado en Cartagena, en la fragata "Santa Rosalia", el 27 de abril de 1767 desde Cartagena para Italia, en AGS 
Marina leg 724 Relación de los religiosos de la Compañia de Jesús que se embarcaron en la Fragata de S.M. nombrada Santa Rosalia En Italia residió en la legación de Bolonia, donde falleció el 1 de septiembre de 1790, en M. LUENGO: Diario..., vol XXIV, ff. 512-540.

63.- Zubiaur era sacerdote operario del Colegio de San Ignacio de Valladolid. Natural de Begoña, donde había nacido en 1717. Embarcado en Ferrol el 25 de mayo de 1767 en el paquebote "San José", Aparece como sacerdote del Colegio Real de Salamanca en las relaciones de 1771, en A.G.S. Dirección General del Tesoro, Inventario 27 Leg 1.

64.- El famoso autor de "Fray Gerundio...", era sacerdote operario del Colegio de Pontevedra. Natural de Vidanes, obispado de León, había nacido el 24 de marzo de 1703 e ingresado en la Compañía de Jesús el 29 de abril de 1719. Tras el decreto de expuisión llegó muy enfermo a Coruña, pero allí fue embarcado el 18 de mayo de 1767 en la Saetía "Santa Maria de la mar" para Ferrol, donde el 25 de ese mismo mes se le trasladó al navío San Juan Nepomuceno. Residente en Bolonia, el 8 de julio de 1773 fue encarcelado por "escrituras temerarias", y "de la audacia con que hablaba de los Soberanos y del Papa", en A.G.S. Estado Leg. 4.737 Juan Zambeccari a Grimaldi Bolonia, 13 de julio de 1773. Murió en Bolonia el 3 de noviembre de 1781.

65.- Las cartas impresas de los superiores de las distintas órdenes religiosas comunicando la Pragmática Sanción y glosando su contenido, pueden encontrarse en el libro 134 de la Nunciatura de España, del Archivo Secreto Vaticano (A.S.V.).

66.- El 19 de junio llegó a Bastia la expedición con los jesuitas andaluces, pero su comandante Lombardón decidió remontar el cabo Corso, la punta septentrional de la isla, y anclar sus barcos en San Florencio, en la costa occidental. Cuando llegó a su destino el 24 de junio, Lombardón encontró en aquella rada los buques de Francisco de Vera con los jesuitas de la Provincia de Toledo. Cuatro dias después fondeaban también los buques de Diego Argote, en su camino hacia Ajaccio.

67.- El barcelonés Antonio Codorniu era sacerdote del Colegio de Gerona, y pertenecía al grupo de jesuitas catalanes de Cervera: Aymerich, Cerdá, Gallisá, Llampillas, Bartolomé Pou y José Pons, entre otros. Embarcó en Salou el 1 de mayo de 1767 en la Saetía "San Ramón". Fue llamado por Marcelino Ménendez y Pelayo, con evidente exageración, el Gracián del siglo XVIII. Murió en Ferrara el 9 de julio de 1770.

68.- Se trataba de los hermanos José y Nicolás Pignatelli. El primero procedía del Colegio de Zaragoza, y embarcó en Salou el 1 de mayo de 1767 en la Saetía "Nuestra Señora del Buen Viaje". Nicolás formaba parte del Colegio de Cordelles o Seminario de Nobles de Barcelona. Fue embarcado en Salou el 1 de mayo de 1767 en la Saetía "San Ramón". José sería el primer General de la nueva Compañía restuarada, y posteriormente beatilicado. Vid. J.M. MARCH : El restaurador de la Compañia de Jesús, beato José Pignatelli y su tiempo 2 Vls., Barcelona 1935-36, y M. BATLLORI: "José Pignatelli: el hombre y el Santo", en La cultura hispano-italiana de los jesuitas expulsos Madrid 1966, pp.311-330.

69.- Referencia al Comisario de Provincia Juan Enríquez, propuesto por el Intendente de Marina de Cartagena juan Domingo de Medina, y designado por el Secretario de Marina, Julián de Arriaga, el 25 de abril de 1767. Vid. A.G.S. Marina Leg. 724 Arriaga a Juan Domingo de Medina Aranjuez, 28 de abril de 1767.

70.- En las relaciones consultades Antonio Zacagnini figura como sacerdote de la Provincia de Toledo, y había actuado como maestro de los Infantes. Fue embarcado en la fragata "Santa Rosalia" el 27 de abril de 1767 desde Cartagena para Italia, en AGS Marina leg 
724 Relación de los religiosos de la Compañia de Jesús que se embarcaron en la Fragata de S.M. nombrada Santa Rosalia. En octubre de 1768 pasó a Génova, donde fijó su residencia.

71.- Juan Vendlingen era como Zacagnini sacerdote de la provincia toledana, y al igual que aquél embarcado en Cartagena en la Fragata "Santa Rosalia" el 27 de abril de 1767.

72.- El nombre completo de este perssonaje era Antonio Alonso Marín, sacerdote del Colegio de Murcia, y Provincial de Toledo. Hizo el viaje a Córcega desde Cartagena a bordo de la fragata inglesa San Jorge el 9 de octubre de 1767, en AGS Marina leg 724 Relación de los Regulares de la Compañia que salieron de este Puerto el dia de la fecha para la Isla de Córcega. Decidió secularizarse, abandonando Ia Compañía. En 1774 residía en Roma, según A.G.S. Dirección General del Tesoro, Inventario 27 Leg. 1.

73.- Antonio Espinosa había traducido la "Historia del Pueblo de Dios, desde su origen hasta el nacimiento del Mesías”, del P. Isaac José Berruyer, publicada en Madrid en 12 vols. por la imprenta de Manuel Fernández entre 1746 y 1750 . Espinosa pertenecía al Colegio de Murcia. Nacido en 1697, fue embarcado el 28 de abril de 1767 en Cartagena en la Urea holandesa "El Buen Amigo" rumbo a Civitavecchia, en AGS Marina leg 724 Certificación de Sebastián Ruiz Contador de la Urca holandesa "El Buen Amigo". Posteriormente residió en la legación de Rávena, falleciendo en Forlí el 4 de marzo de 1780.

74.- El P. Navarro fue embarcado el 28 de abril de 1767 en Cartagena en la Urca holandesa "Maria Tcresa", cn AGS Marina leg 724 Certificación de Tomás Bugeda Contador de la Urca holandesa "Maria Teresa". Murió en Forlí el 26 de abril de 1780.

75.- El P. Eustaquio Medina embarcó en Cartagena el 28 de abril de 1767 en la Fragata danesa "la Concordia", en A.G.S. Marina leg 724 Certificación de Vicente Sessé Contador de la Fragata danesa "La Concordia" . Pasó a residir posteriormente en la legación de Rávena.

76.- Uno de los enfermos desembarcados en Civitavecchia de la Provincia de Andalucia cra el estudiante del Colcgio de San Hermenegildo de Sevilla Nicolás Valcárcel. El 8 de noviembre de 1767, ya restablecido, pasó a Córcega. Vid. A.G.S. Gracia y Justicia Leg. 667 Grimaldi a Roda, 11 de noviembre de 1767.

77.- Decía este párrafo: "el más sensible a nuestro paternal corazón ha sido ciertamente éste que nos causa la última carta de V.M. en que nos manifiesta la resolución que ha tomado de exterminar de todos sus dominios a los Religiosos de la Compañía de Jesús, tu quoque fili mi, conque nucstro carísimo hijo el Rey Carlos tercero ha de ser el que ponga el colmo al cáliz de nuestras aflicciones...". Copias del tex to corrieron profusamente entre los jesuitas exilados. El P. Luengo Ja recoge en italiano y en traducción al español en el tomo I de sus Papeles curiosos.

78.- El P. José Tirado era sacerdote del Colegio de Toledo. Pasó a Córcega embarcado en la urca holandesa "La Posta del Mar", que partió de Cartagena el 28 de abril de 1767, cn A.G.S.Marina leg 724 Certificación de Juan Lambertos Contador de la Ura holandesa "La Posta del mar".En 1773 residía en Forli, en la legación de Rávena.

79.- El efecto, el P. Antonio Eximeno, sacerdote de la Provincia de Aragón, era en el momento de la expulsión profesor de Matemáticas en el Colegio Militar de Segovia. Natural de Valencia había nacido en 1729. Embarcado el 25 de Mayo de $1767 \mathrm{cn}$ Ferrol en el Navio "San Genaro", pronto sc separó de la Compañía secularizandose en 1767. A mediados de octubre de ese año se hallaba en Roma, en A.G.S. Estado Leg. 5.049 Azpurt a Grimaldi 
Roma, 26 de noviembre de 1767: Sobre la llegada a Roma de Antonio Eximendo y sus deseos de secularizarse. En octubre de 1778 se le duplicó la pensión, en AGS Estado Leg. 5.041 Grimaldi a Floridablanca, Roma 29 de octubre de 1778 . Falleció en Roma el 9 de junio de 1808.

80.- Se trata de Tomás Cerdá, sacerdote del Colegio Imperial de Madrid, y Cosmógrafo Mayor del Consejo de Indias. Fue embarcado en el Chambequin "Garzota" el 27 de abril de 1767 desde Cartagena para Italia, en AGS Marina leg 724 Relación de los religiosos de la Compañia de Jesús que se embarcan en el chambequin de S.M. nombrado el Garzota. El Consejo Extraodinario de 25 de octubre de 1767 consultó su petición de que se le continuase el sueldo del empleo de Cosmógrafo Mayor, en A.G.S. Gracia y Justicia leg 688 Consejo Extraordinario de 25 de octubre de 1767. Residente en Forlí, legación de Rávena, en 1773.

81.- Se refería al P. Miguel Benavente, que se embarcó el 27 de abril en Cartagena en la Fragata "Santa Rosalia". Como los anteriores residía en Forlí en tiempos de la extinción.

82.- El P. Juan Antonio Mayo era sacerdote del Noviciado de Madrid. Había navegado en la urca holandesa "El Falcón". Murió tísico el 1 de Julio de 1767.

83.- Miguel Ignacio Ordeñana era sacerdote y catedrático de Prima del Colegio Real de Salamanca. Natural de Bilbao, donde nació el 16 de febrero de 1716. Jesuita desde el 3 de mayo de 1731 y profeso de cuarto voto, fue embarcado el 25 de Mayo de $1767 \mathrm{en} \mathrm{el}$ Ferrol en el navio "San Genaro". Murió en Bolonia el 27 de enero de 1784.

84.- Hay una cierta coincidencia en la descripción de la casa corsa con la que hace Paul ARRIGHI: La vie quotidienne en Corse au XVIII siècle París 1970, pp. 37-42.

85.- Se trataba del P. Francisco Javier Godoy, sacerdote de la Casa Profesa de Sevilla. Embarcó en Cartagena en el navio holandés "Catalina Polonia" el 9 de octubre de 1767 para Córcega, en AGS Marina leg 724 Relación de los Regulares de la Compañia que salieron de este Puerto el dia de la fecha para la Isla de Córcega. Residió en Bolonia en 1771, en AGS Dirección general del Tesoro, Inventario 27 Leg 12 Libro de los Ex-jesuitas, Trimestre $3^{\circ}$ de 1771 , pero en 1773 aparece como residente en la legación de Rávena. Falleció en Faenza el 23 de agosto de 1783.

86.- Sobre el carácter corso, según lo vieron diversos memorialistas del XVIII, vid. Paul ARRIGHI: Op. cit. pp.203-219.

87.- James Boswell, que publicó en 1768 un Joumal of Tour to Corsica, se admiró de que dos mujeres, tan robustas como hombres, se encargaran de transportar sobre sus cabezas su voluminoso equipaje.

88.- En opinión de Boswell, "La Corse est peut-être le seul pays sur la surface du globe où le luxe n'ait jamais pénétré", citado en Paul ARRIGHI: La vie quotidienne... p. 49.

89.- El abate Gaudin afirmaba en su Voyage en Corse... publicado en París en 1787, que "Du pain qui, même dans quelques pièves, n'est fait qu'avec des châtaignes...". Cit. en Paul ARRIGHI. Op. cit. p.56. 